\title{
Willardiines Differentiate Agonist Binding Sites for Kainate- versus AMPA-preferring Glutamate Receptors in DRG and Hippocampal Neurons
}

\author{
Linda A. Wong, ${ }^{1}$ Mark L. Mayer, ${ }^{1}$ David E. Jane, ${ }^{2}$ and Jeffrey C. Watkins ${ }^{2}$ \\ 'Laboratory of Cellular and Molecular Neurophysiology, NICHD, National Institutes of Health, Bethesda, Maryland 20892 \\ and ${ }^{2}$ Department of Pharmacology, School of Medical Sciences, University of Bristol, Bristol BS8 1TD, United Kingdom
}

Concentration jump responses to 5-substituted (S)-willardiines were recorded from dorsal root ganglion (DRG) and hippocampal neurons under voltage clamp. After block of desensitization by concanavalin- $A$, dose-response analysis for activation of kainate-preferring receptors in DRG neurons gave the potency sequence trifluoromethyl $>$ iodo $>$ bromo $\approx$ chloro $>$ nitro $\approx$ cyano $>$ kainate $>$ methyl $>$ fluoro $>$ $(R, S)$-AMPA $\gg$ willardiine; $\mathrm{EC}_{\mathrm{so}}$ values for the most and least potent willardiine derivatives, 5-trifluoromethyl (70 $\mathrm{nm}$ ) and 5-fluoro $(69 \mu \mathrm{M})$, differed 1000 -fold. The potency sequence for equilibrium responses at AMPA-preferring receptors in hippocampal neurons was strikingly different from that obtained in DRG neurons: fluoro $>$ cyano $\approx$ trifluoromethyl $\approx$ nitro $>$ chloro $\approx$ bromo $>(R, S)$-AMPA $>$ iodo $>$ willardiine $>$ kainate $>$ methyl. In hippocampal neurons $\mathrm{EC}_{50}$ values for the most and least potent willardiine derivatives, 5-fluoro (1.5 $\mu \mathrm{M})$ and 5-methyl (251 $\mu \mathrm{M})$, differed only 170-fold. Consistent with equilibrium potency measurements, in DRG neurons the kinetics of deactivation for willardiines, recorded following a return to agonist-free solution, were rapid for 5 -fluoro ( $\tau_{\text {off }}=43 \mathrm{msec}$ ) but slow for 5 -iodo $\left(\tau_{\text {off }}=4.2 \mathrm{sec}\right.$ ), while the opposite sequence was observed for hippocampal neurons, slow for 5 -fluoro $\left(\tau_{\text {off }}=2.1 \mathrm{sec}\right)$ and rapid for 5 -iodo $\left(\tau_{\text {uff }}=188 \mathrm{msec}\right)$. The kinetics of recovery from desensitization showed comparable agonist- and cell-dependent differences. Structure-activity analysis for agonist responses recorded from DRG and hippocampal neurons suggests that for both kainate-preferring and AMPA-preferring receptors the binding of willardiines involves interactions with polar groups such that potency is related to ionization of the uracil ring, and hence the electron-withdrawing ability of the 5-position substituent. However, kainate-preferring receptors differ from AMPA-preferring receptors in possessing a lipophilic pocket that further enhances agonist potency by hydrophobic bonding of the 5-substituent. In contrast, AMPApreferring receptors lack such a lipophilic site, and for 5-position substituents of the same electron-withdrawing ability, potency decreases with increase in size.

\footnotetext{
Received Sept. 30, 1993; accepted Dec. 21, 1993.

We thank Christine Winters for preparation of hippocampal cultures, Dr. C. Bigge for the gift of $(R, S)$-AMPA, Dr. I. Mintz for demonstrating the preparation of DRG neurons, and Drs. C. McBain and D. Patneau for reading the manuscript.

Correspondence should be addressed to Dr. M. L. Mayer, Building 49, Room 5A78, National Institutes of Health, Bethesda, MD 20892

Copyright (C) 1994 Society for Neuroscience $0270-6474 / 94 / 143881-17 \$ 05.00 / 0$
}

IKey words: glutamate, kainate, AMPA, willardiine, desensitization, dose-response, dorsal root ganglion, hippocampus]

Convincing evidence suggesting the occurrence of a glutamate receptor subtype preferentially activated by kainic acid first came from studies on sensory neuron axons in the dorsal root of the rat spinal cord (Agrawal and Evans, 1986). These experiments revealed quisqualate and AMPA to be 30 and 70 times less potent than kainate; in contrast, for hippocampal neurons the potency sequence for these agonists is reversed, with $(S)$-quisqualate and $(R, S)$-AMPA 160 and 13 times more potent than kainate (Patneau and Mayer, 1990). Such experiments suggest differences in the agonist recognition sites for kainate- versus AMPA-preferring glutamate receptors, but give no clue as to the molecular features important for the selective action of agonists at each receptor subtype. Subsequent analysis of the response of dorsal root ganglion (DRG) neurons to excitatory amino acids revealed strong desensitization of responses to glutamate, kainate, and domoate (Huettner, 1990), while in hippocampal neurons kainate and domoate evoke apparently nondesensitizing responses (Kiskin et al., 1986; Patneau and Mayer, 1990; but see Patneau et al., 1993). One interpretation of these results would be that for both AMPA-preferring and kainatepreferring subtypes of glutamate receptor the active and desensitized states show marked differences in their relative affinity for agonists (Patneau and Mayer, 1991; Mayer et al., 1992; Patneau et al., 1992).

The recent isolation of multiple gene families for glutamate receptor subunits, and analysis of their functional response following cxpression in vitro, provides further support for the existence in CNS tissue of multiple subtypes of native glutamate receptor activated by kainic acid, with the broad families GluR-1 to GluR-4 (GluR-A to GluR-D), GluR-5 to GluR-7, and KA-1 and KA-2 corresponding to the functionally defined AMPAand kainate-preferring subtypes expressed in hippocampal and DRG neurons, respectively (for reviews, see Sommer and Seeburg, 1992; Hollman and Heinemann, 1993). In order to facilitate further the differentiation of native AMPA- and kainatepreferring glutamate receptor subtypes, we describe here the action on DRG and hippocampal neurons of a series of 5 -substituted $(S)$-willardiines, heterocyclic amino acid agonists of novel structure (Patneau et al., 1992) that we find to show greater discrimination between AMPA- and kainate-preferring receptors than previously characterized agonists. Our results suggest a hydrophobic pocket in the agonist binding site for 
kainate- but not AMPA-preferring glutamate receptors, thus opening new approaches for the design of kainate receptorselective agonists and antagonists.

Some of our results have been presented previously in abstract form (Wong et al., 1992).

\section{Materials and Methods}

Cell preparation. Rat DRG neurons were dissociated based on a protocol described previously (Mintz et al., 1992). In brief, DRGs were dissected from P8-P13 Sprague-Dawley rat pups and incubated at $35^{\circ} \mathrm{C}(20 \mathrm{~min})$ in an enzyme solution consisting of $82 \mathrm{~mm} \mathrm{Na} \mathrm{NO}_{4}, 30 \mathrm{~mm} \mathrm{~K} \mathrm{SO}_{4}, 5$ $\mathrm{mm} \mathrm{MgCl}_{2}, 10 \mathrm{~mm}$ HEPES, $10 \mathrm{~mm}$ glucose, $0.001 \%$ phenol red, and Sigma type XXIII protease $(0.6 \mathrm{mg} / \mathrm{ml})$. Following this, the tissue was rinsed and triturated in enzyme-free solution containing trypsin inhibitor (Sigma; $1 \mathrm{mg} / \mathrm{ml}$ ) and bovine serum albumin (Sigma; $1 \mathrm{mg} / \mathrm{ml}$ ). The freshly dissociated cells were then left to settle at room temperature for more than $12 \mathrm{hr}$. Four hours prior to recording, the cells were plated onto poly-L-lysine (Sigma)-coated dishes containing minimum essential medium (GIBCO \#320-1090) supplemented with $0.7 \%$ methylcellulose $2 \mathrm{~mm}$ L-glutamine (GIBCO), $10 \mathrm{~mm}$ D-glucose (Sigma), 10\% fetal bovine serum (GIBCO), and $0.03 \%$ gentamicin (Sigma), and maintained at $35^{\circ} \mathrm{C}$ in a humidified incubator $\left(5 \% \mathrm{CO}_{2}, 95 \%\right.$ air). Rat hippocampal cultures were prepared from E22/23 Sprague-Dawley rat fetuses according to previously published protocols (Mayer et al., 1989) in which the hippocampi were dissected, incubated in an enzyme solution containing papain (Worthington; $100 \mathrm{U}$ ), and then dissociated by trituration prior to plating on a confluent glial cell feeder layer.

Recording. Experiments were conducted at room temperature on acutely dissociated small-diameter (20-30 $\mu \mathrm{M})$ DRG neurons, and on hippocampal neurons in primary culture. Voltage clamp was performed using the whole-cell, patch-clamp technique (Hamill et al., 1981) and an Axopatch-1C amplifier for experiments on DRG neurons; accurate measurement of larger-amplitude currents in hippocampal neurons required use of an Axoclamp-2A amplifier operating in discontinuous voltage-clamp mode (switching at $\sim 10 \mathrm{kHz}$ ). Fire-polished glass pipettes had tip resistances of 4-7 M $\Omega$ when filled with $125 \mathrm{~mm} \mathrm{CsMeSO}_{3}, 15$ mм CsCl, 5 mм CsBAPTA, $10 \mathrm{~mm}$ HEPES, $3 \mathrm{~mm} \mathrm{MgCl}_{2}, 0.5 \mathrm{~mm}$ $\mathrm{CaCl}_{2}$, and $2 \mathrm{mM} \mathrm{Mg}$-ATP (titrated to $\mathrm{pH} 7.2$ with $\mathrm{CsOH}$ ). Agonistactivated currents were filtered at $0.1-1.0 \mathrm{kHz}$ (eight-pole Bessel filter) and digitized at $0.5-10 \mathrm{msec}$ per point using an Instrutech ITC-16 interface and a Macintosh IIfx computer controlled by software written by J. W. Nash (Synergistic Research Systems, Silver Spring, MD). The external solution consisted of (in $\mathrm{mM}$ ) $160 \mathrm{NaCl}, 2.5 \mathrm{KCl}, 2 \mathrm{CaCl}_{2}, 1$ $\mathrm{MgCl}_{2}, 10 \mathrm{HEPES}, 10$ glucose, and $0.001 \%$ phenol red (titrated to $\mathrm{pH}$ 7.3 with $\mathrm{NaOH})$ and contained TTX (500 nM); bicuculline methochloride, $5 \mu \mathrm{M}$, was added for experiments on hippocampal neurons to block inhibitory synaptic currents.

Drug application. Agonists were applied through a linear array of nine glass barrels, outer diameter $400 \mu \mathrm{m}$ (Garner Glass), positioned 100 $150 \mu \mathrm{m}$ away from the cell under study. Rapid solution exchange was attained using solenoid valves to switch the flow between adjacent barrels immediately after a stepper motor moved the array to the desired position. Stock solutions of kainate, AMPA, and willardiines were prepared by dissolving the drugs in extracellular recording solution, adding $\mathrm{NaOH}$ as needed to maintain neutral $\mathrm{pH}$, and were stored at $-20^{\circ} \mathrm{C}$. (S)-Willardiine analogs were synthesized and purified by resin chromatography (see Patneau et al., 1992); $(S)$-willardiine and its halogenated derivatives have since become commercially available from Tocris Neuramin Ltd. (Bristol, UK). Kainate was obtained from Sigma; $(R, S)$-AMPA was a gift from Parke-Davis (Ann Arbor, MI); other reagents were obtained from Aldrich, Calbiochem, Sigma, or Tocris Neuramin, as required.

Analysis. Dose-response curves were fit with the following equation:

$$
I=I_{\max } \times\left(1 / 1+\left\{\mathrm{EC}_{\mathrm{s0}} /[\text { Dose }]\right\}^{n}\right)
$$

Unless stated otherwise, data values are presented as mean \pm SD. Statistical analysis was performed using one-way analysis of variance (ANOVA) or a two-tailed paired $t$ test.

\section{Results}

Willardiine responses in DRG and hippocampal neurons

DRG neurons show strong desensitization in response to glutamate and quisqualate, while responses to kainate and domoate show less desensitization (Huettner, 1990). In the present experiments, when applied to DRG neurons at concentrations known to be maximally effective (see Fig. 3), responses to 5 -substituted $(S)$-willardiines were similar to those evoked by glutamate, with moderately rapid and pronounced desensitization, stronger than that evoked by kainate (Fig. $1 A$ ). On average, when applied for $2 \mathrm{sec}$, responses to halogenated willardiines descnsitized by $88.4 \pm 6.4 \%$ (pooled responses for 74 observations, 19 cells), while in the same cells responses to kainate desensitized by only $54.6 \pm 9.1 \%$ (38 observations, 19 cells). The degree of desensitization evoked by willardiines differed substantially between DRG and hippocampal neurons; for DRG neurons there was no significant difference (one-way ANOVA) in the degree of desensitization evoked by the above willardiines, while for hippocampal neurons the same agonists showed marked differences in the degree of desensitization (Fig. $1 B)$, such that desensitization evoked by $(S)$-5-fluorowillardiine, $92.5 \pm 3 \%$, was much greater than that evoked by $(S)$-5-iodowillardiine, $63.6 \pm 3 \%$ (see Patneau et al., 1992, Table 1).

In individual DRG neurons the peak amplitude of responses to willardiines were significantly smaller $(p<0.01)$ than those evoked by kainate (Fig. $1 A$ ), in contrast to results obtained in hippocampal neurons, for which the maximum amplitudes of responses to willardiines were approximately twice those to kainate (Fig. $1 B$ ). The amplitude ratios for peak responses in $D R G$ neurons with respect to kainate were, for $(S)$-5-fluorowillardiine, $0.61 \pm 0.15,16$ cells; $(S)$-5-chlorowillardiine, $0.72 \pm$ $0.12,21$ cells; $(S)$-5-bromowillardiine, $0.70 \pm 0.06,16$ cells; $(S)$-5-iodowillardiine, $0.70 \pm 0.08,14$ cells; $(S)$-5-cyanowillardiine, $0.76 \pm 0.06,4$ cells; $(S)$-5-nitrowillardiine, $0.69 \pm 0.10$, 19 cells; $(R, S)$-AMPA, $0.39 \pm 0.07,5$ cells. The lower relative efficacy of willardiines with respect to kainate in DRG versus hippocampal neurons was not an artifact resulting from incomplete recovery from desensitization in DRG neurons evoked by a prior application of agonist, since in all experiments both rundown and incomplete recovery from desensitization were controlled for by routinely bracketing responses to individual willardiines with test responses to kainate. However, desensitization during the rising phase of the response to willardiines could potentially reduce the peak amplitude of agonist responses in DRG neurons, since it has been previously demonstrated that unless glutamate, quisqualate, and AMPA are applied using a rapid perfusion system, responses to these agonists are undetectable (Huettner, 1990).

In order to measure the efficacy and potency of willardiines at kainate-preferring receptors independent of desensitization, we took advantage of the observation that the lectin concanavalin-A (ConA) greatly attenuates desensitization of glutamate receptor responses in DRG neurons without altering the $\mathrm{EC}_{50}$ value for kainate or domoate (Huettner, 1990). In the present study, pilot experiments showed that treatment with $300 \mu \mathrm{g} / \mathrm{ml}$ ConA for as little as $1 \mathrm{~min}$ profoundly inhibited desensitization evoked by maximally effective concentrations of all agonists examined (Fig. 2); the amount of residual desensitization remaining after treatment with ConA was, for kainate, $4.4 \pm 2.4 \%$ (5 cells); $(S)$-5-fluorowillardiine, $11.3 \pm 4.4 \%$ (4 cells); $(S)$-5-chlorowillardiine, $18.4 \pm 10.1 \%$ (5 cells); $(S)-5$ bromowillardiine, $15.2 \pm 6.5 \%$ (5 cells); $(S)$-5-iodowillardiine, $15.5 \pm 5.3 \%$ (5 cells); $(S)$-5-cyanowillardiine, $15.0 \pm 6.3 \%$ (3 cells); $(S)$-5-nitrowillardiine, $22.3 \pm 7.6 \%(3$ cells $)$; and $(R, S)$ AMPA, $32.3 \pm 6.0 \%$ ( 5 cells). The residual desensitization remaining after treatment with ConA was also noted by Huettner 
A

\section{DRG}
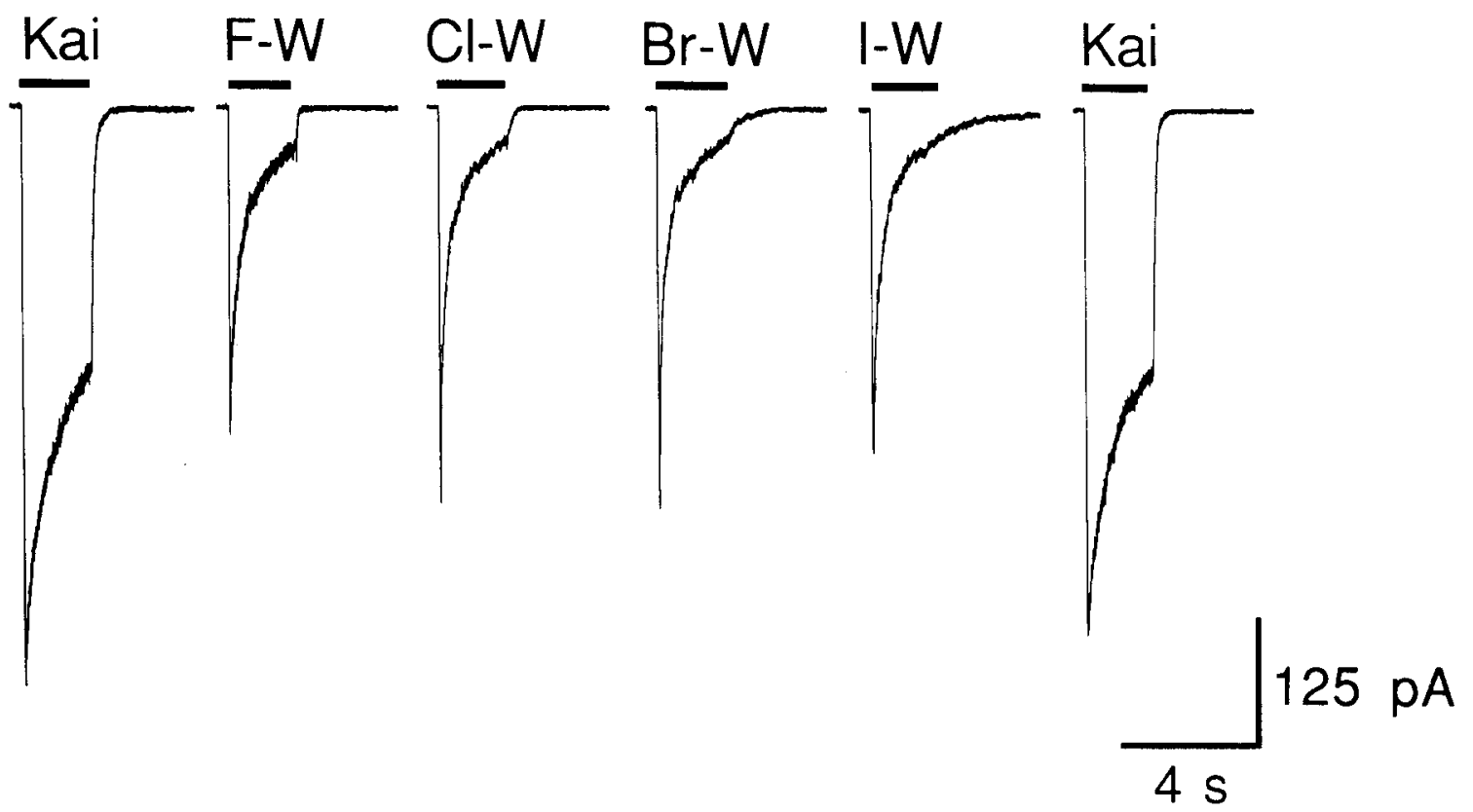

\section{Hippocampus}

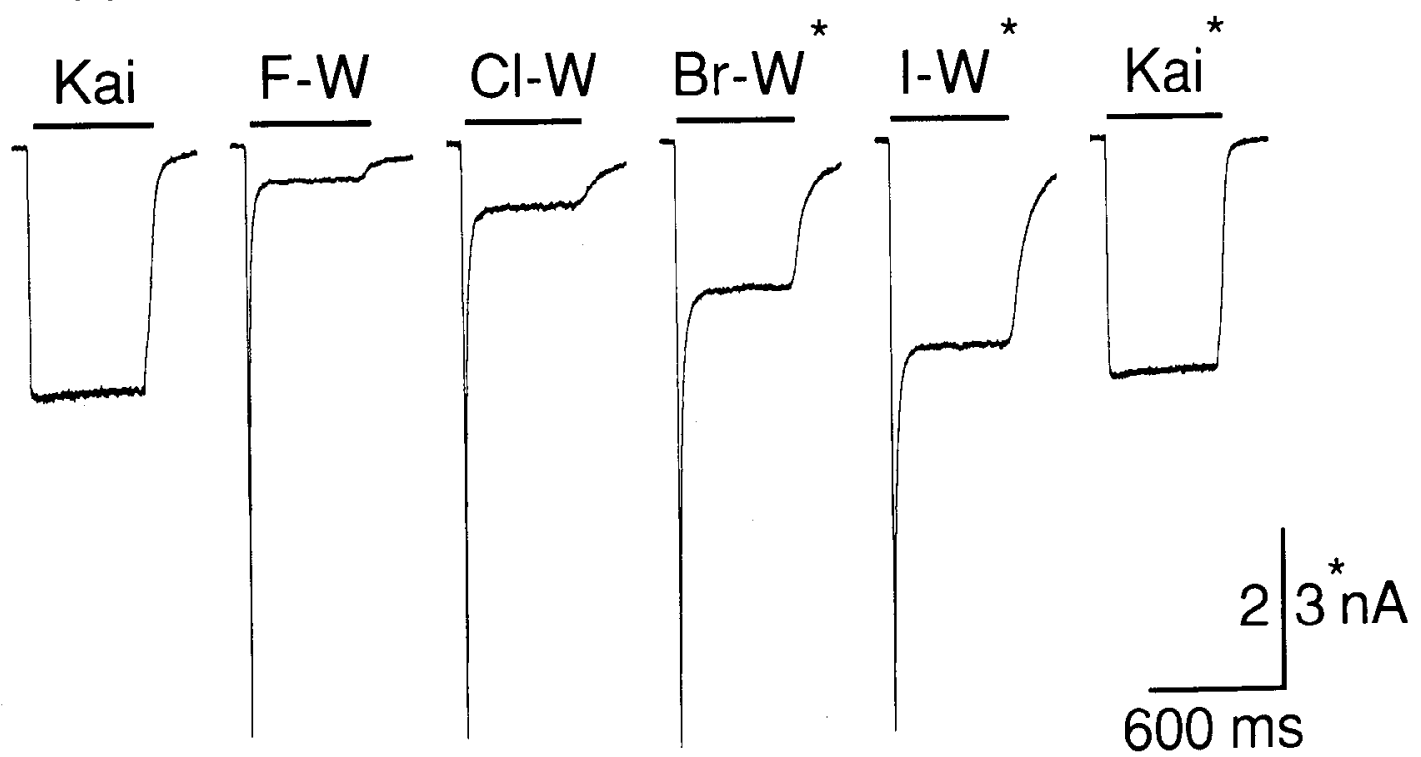

Figure 1. Functional responses to 5-substituted willardiines and to kainate differ in DRG versus hippocampal neurons. $A$ shows strongly desensitizing responses of the same DRG neuron to $1.2 \mathrm{~mm}$ kainate $(\mathrm{Kai}), 10 \mathrm{mM}(S)$-5-fluorowillardiine $(F-W), 300 \mu \mathrm{M}(S)-5$-chlorowillardiine $(C l$-W $)$, $100 \mu \mathrm{M}(S)$-5-bromowillardiine $(B r-W)$, and $30 \mu \mathrm{M}(S)$-5-iodowillardiine $(I-W)$. At these concentrations agonist responses are close to maximum (see Fig. 3); note that the response to kainate is larger than that to the other agonists. For comparison, $B$ shows responses of a hippocampal neuron to maximally effective concentrations of kainate $(6 \mathrm{~mm}), \mathrm{F}-\mathrm{W}(1 \mathrm{~mm}), \mathrm{Cl}-\mathrm{W}(3 \mathrm{~mm}), \mathrm{Br}-\mathrm{W}(3.5 \mathrm{~mm})$, and I-W (8 mM) taken from Figure 3 in Patneau et al. (1992); note that the response to kainate is nondesensitizing and smaller than responses to the willardiine analogs.

(1990), and did not diminish following prolonged application of lectin. Our observation that desensitization of responses to AMPA is strongly inhibited by ConA (Fig. $2 B$ ) indicates that DRG neurons exhibit few, if any, functional AMPA-preferring glutamate receptors, since we have previously demonstrated a preferential action of ConA on desensitization at kainate- versus AMPA-preferring glutamate receptor subtypes (Partin et al., 1993; Wong and Mayer, 1993); this conclusion is further sup- 


\section{A DRG Concanavalin A}

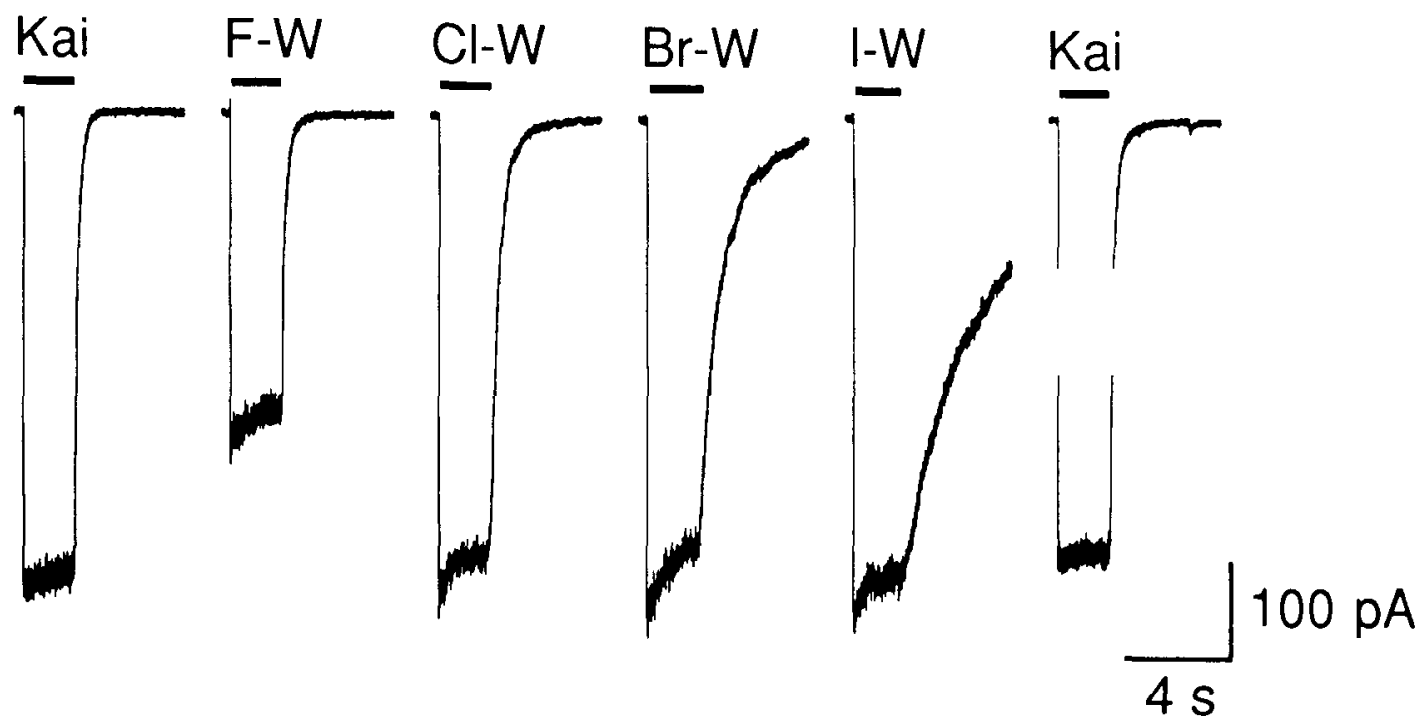

B

\section{$\square$ Control $\square$ Concanavalin A}

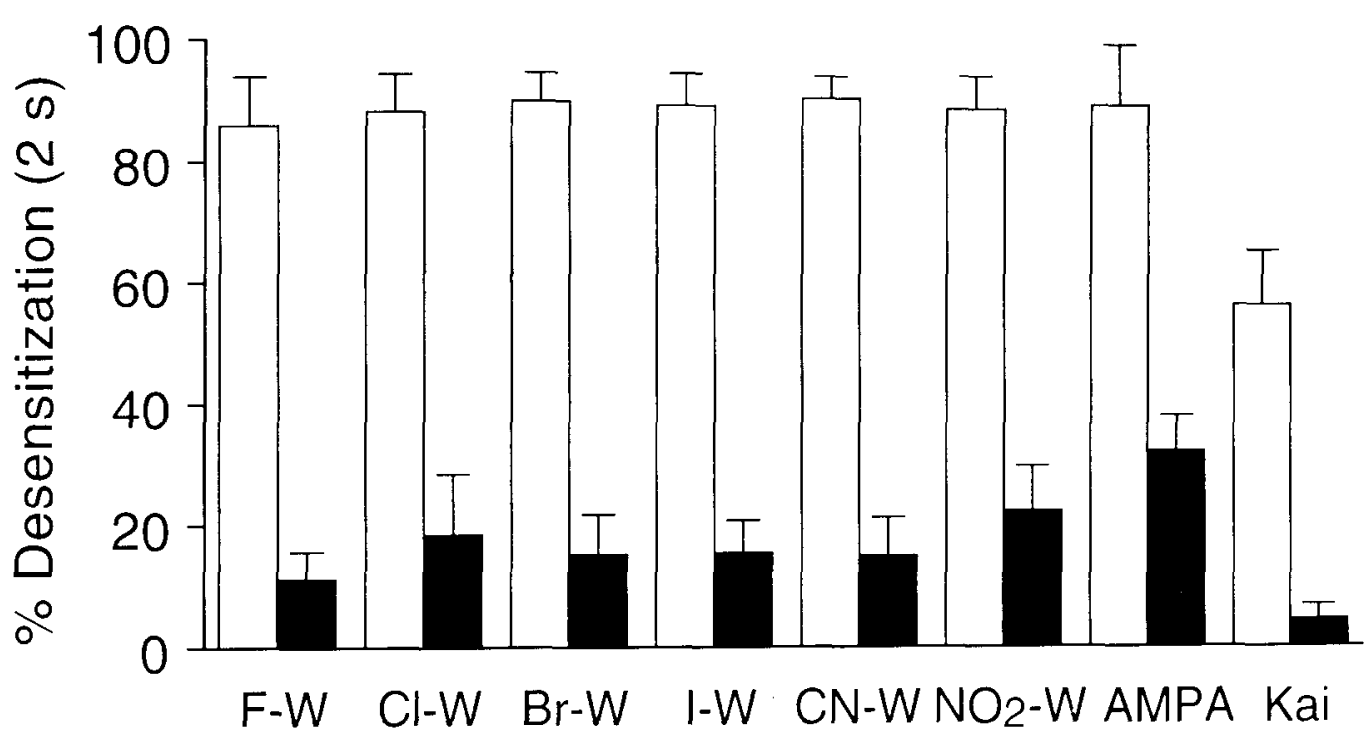

Figure 2. ConA inhibits desensitization to willardiines, AMPA, and kainate in DRG neurons. $A$ shows responses of a DRG neuron treated with ConA $(300 \mu \mathrm{g} / \mathrm{ml})$ to kainate $(1.2 \mathrm{~mm}),(S)$-5-fluorowillardiine $(10 \mu \mathrm{mm}),(S)$-5-chlorowillardiine $(300 \mu \mathrm{M})$, $(S)-5$-bromowillardiine $(100 \mu \mathrm{M})$, and $(S)$-5-iodowillardiine $(30 \mu \mathrm{M})$; agonists were applied for $2 \mathrm{sec}$. The smaller-amplitude response to $(S)$-5-fluorowillardiine reflects partial agonist action. $B$ plots the degrec of desensitization for responses to some 5-substituted willardiines, to AMPA, and to kainate, all applied for 2 sec at concentrations approximately 100 times the $\mathrm{EC}_{50}$ (see Fig. 3) in control DRG neurons, and in DRG neurons treated with ConA; the percentage desensitization at $2 \mathrm{sec}$ was defined as $\left[1-\left(I_{2 \mathrm{~s}} / I_{\text {peak }}\right)\right] \times 100$.

ported by our observation that cyclothiazide, a drug that selectively abolishes desensitization at AMPA- but not kainate-preferring glutamate receptors (Partin et al., 1993; Patneau et al., 1993; Yamada and Tang, 1993), does not potentiate responses to AMPA in DRG neurons (L. A. Wong and M. L. Mayer, unpublished observations).
Agonist potency for activation of glutamate receptors in $D R G$ versus hippocampal neurons

Dose-response analysis for $(S)$-willardiine, and a series of eight 5 -substituted willardiine analogs containing substituents designed to explore the influence of size, electronegativity, and 
A
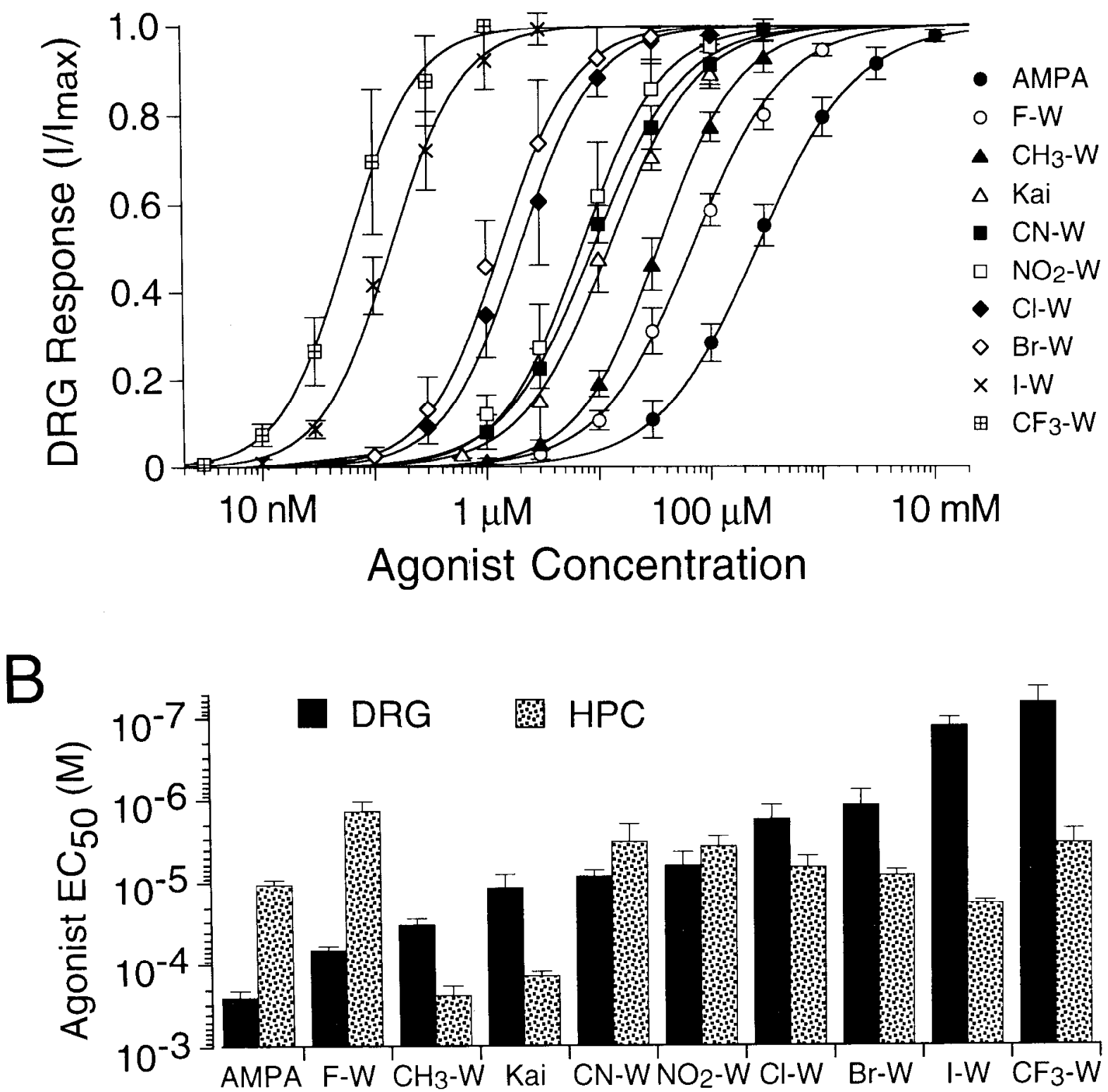

Figure 3. Dose-response analysis for agonist responses in DRG and hippocampal neurons. $A$ plots peak amplitude dose-response curves obtained from DRG neurons treated with ConA for $(R, S)$-AMPA, kainate, $(S)$-5-fluorowillardiine, $(S)$-5-methylwillardiine, $(S)$-5-cyanowillardiine, $(S)$-5nitrowillardiine, $(S)$-5-chlorowillardiine, $(S)$-5-bromowillardiine, $(S)$-5-iodowillardiine, and $(S)$-5-trifluoromethylwillardiine. Data points represent average values (mean + SD) from three to seven cells per agonist (see Table 1) normalized with respect to the maximum current $\left(I_{\text {max }}\right.$ ) for each agonist and fit with Equation 1. $B$ plots the $\log \mathrm{EC}_{50}$ values for the above agonists for responses in DRG neurons [rank order of agonist potency: trifluoromethyl $>$ iodo $>$ bromo $\approx$ chloro $>$ nitro $\approx$ cyano $>$ kainate $>$ methyl $>$ fluoro $>(R, S)$-AMPA], and for responses in hippocampal neurons [rank order of agonist potency: fluoro $>$ cyano $\approx$ trifluoromethyl $\approx$ nitro $>$ chloro $\approx$ bromo $>(R, S)$-AMPA $>$ iodo $>$ kainate $>$ methyl].

hydrophobicity on kainate receptor responses, was performed in DRG neurons pretreated with ConA as described above; in addition, we made measurements for the reference compounds kainate and $(R, S)$-AMPA. Agonists were routinely applied for $2 \mathrm{sec}$, except for low concentrations of the more potent agonists, for which applications as long as $30 \mathrm{sec}$ were required to allow responses to reach equilibrium. (S)-Willardiine was not sufficiently potent to allow an estimate of its $\mathrm{EC}_{50}$, but for the other agonists we obtained full dose-response curves from individual cells, which were fit using Equation 1, and the results pooled for statistical analysis (Table 1).

For illustrative purposes data values from three to seven cells per agonist were normalized with respect to the estimated maximum response and pooled (Fig. $3 A$ ). The rank order of agonist potency for 5-substituted $(S)$-willardiines was trifluoromethyl $>$ iodo $>$ bromo $\approx$ chloro $>$ nitro $\approx$ cyano $>$ kainate $>$ methyl $>$ fluoro $>(R, S)$-AMPA $\gg$ willardiine. Of the 5-substituted willardiines, $\mathrm{EC}_{50}$ values for the most and least potent agonists, $(S)$-5-trifluoromethylwillardiine $70 \mathrm{~nm}$ and $(S)$-5-fluorowillardiine $69 \mu \mathrm{M}$, differed 1000-fold (see Table 1). For kainate and $(R, S)$-AMPA the $\mathrm{EC}_{50}$ values differed only 22-fold; the low potency of $(R, S)$-AMPA $\left(\mathrm{EC}_{50}=260 \mu \mathrm{M}\right)$ and the $\mathrm{EC}_{50}$ for kainate of $12 \mu \mathrm{M}$ are in good agreement with valucs obtained by Huettner (1990). In contrast to Hill coefficients of 1.0 obtained by Huett- 


\begin{tabular}{|c|c|c|c|}
\hline Agonist & $\begin{array}{l}\text { DRG EC } E_{50} \\
(\mu \mathrm{M})\end{array}$ & $\begin{array}{l}\operatorname{HPC~EC}_{50} \\
(\mu \mathrm{M})\end{array}$ & $\begin{array}{l}\text { Ratio } \\
\text { HPC: } \\
\text { DRG }\end{array}$ \\
\hline$(S)-5-\mathrm{CF}_{3}$-willardiine & $0.074 \pm 0.03$ & $4.00 \pm 1.61$ & 54 \\
\hline (S)-5-I-willardiine & $0.14 \pm 0.03$ & $19.2 \pm 1.92$ & 137 \\
\hline (S)-5-Br-willardiine & $1.36 \pm 0.58$ & $8.82 \pm 1.29$ & 6.5 \\
\hline (S)-5-Cl-willardiine & $1.99 \pm 0.85$ & $7.28 \pm 2.06$ & 3.7 \\
\hline$(S)-5-\mathrm{NO}_{2}$-willardiine & $7.01 \pm 2.88$ & $4.10 \pm 1.45$ & 0.6 \\
\hline (S)-5-CN-willardiine & $8.96 \pm 1.56$ & $3.75 \pm 1.57$ & 0.4 \\
\hline Kainate & $12.4 \pm 2.92$ & $143 \pm 17$ & 11.5 \\
\hline (S)-5-Me-willardiine & $34.1 \pm 6.01$ & $251 \pm 70$ & 7.4 \\
\hline$(S)-5-F$-willardiine & $68.8 \pm 7.39$ & $1.47 \pm 0.39$ & 0.02 \\
\hline$(R, S)$-AMPA & $261 \pm 51.9$ & $11 \pm 1.5$ & 0.04 \\
\hline (S)-willardiine & $>1000$ & $44.8 \pm 15.0$ & - \\
\hline
\end{tabular}

$\mathrm{EC}_{50}$ values were derived from analysis of 3-10 dose-response curves per agonist for DRG neurons (three to seven cells) and 8-12 dose-response curves per agonist for hippocampal (HPC) neurons (four to seven cells) using Equation 1. DRG neurons were pretreated with ConA to abolish desensitization. Responses in hippocampal neurons were measured at equilibrium; $\mathrm{EC}_{50}$ values are taken from Patneau et al. (1992) and Patneau and Mayer (1990), except for $\mathrm{CN}_{-}, \mathrm{CF}_{3^{-}}$, and Me-willardiine.

ner (1990) for domoate, kainate, quisqualate, and glutamate, in the present experiments Hill coefficients for 5-substituted willardiines were $>1.0$ (mean $=1.24 \pm 0.13$; range, 1.05-1.39); for kainate the Hill coefficient was 1.12. Because the perfusion system used for construction of dose-response curves allowed us to test only a single agonist per cell, we were unable to test in the same experiments for agonist-dependent differences in the amplitude of the maximum response evoked by various willardiines; this issue was addressed subsequently by applying maximally effective concentrations of these agonists to single DRG neurons (Fig. 4) as described later.

In previous experiments on hippocampal neurons (Patneau et al., 1992) equilibrium dose-response analysis was performed for a subset of the $(S)$-willardiines tested on DRG ncurons; to allow comparison with results obtained for newly synthesized compounds subsequently tested on DRG neurons we performea additional dose-response analysis for the action of $(S)-5$-cyanowillardiine, $(S)$-5-methylwillardiine, and $(S)$-5-trifluoromethylwillardiine on glutamate receptors expressed in hippocampal neurons. The potency sequence for willardiine responses in hippocampal neurons was fluoro $>$ cyano $\approx$ trifluoromethyl $\approx$ nitro $>$ chloro $\approx$ bromo $>(R, S)$-AMPA $>$ iodo $>$ willardiine $>$ kainate $>$ methyl, strikingly different from that observed in DRG neurons. For comparative purposes Figure $3 B$ plots the $\log$ of the $\mathrm{EC}_{50}$ values obtained from $\mathrm{DRG}$ neurons relative to those observed in hippocampal neurons. It is of interest that for the halogenated willardiine derivatives there is an inverse relationship for the potency sequence in DRG versus hippocampal neurons, while other compounds act with similar potency in both tissues [note the similar $\mathrm{EC}_{50}$ in $\mathrm{DRG}$ and hippocampal neurons for the pair $(S)$-5-cyanowillardiine and $(S)$-5-nitrowillardiine].

\section{Partial agonist activity for responses at kainate-preferring receptors}

In preliminary experiments to test the efficacy with which ConA reduces desensitization to willardiines in DRG neurons, we noted that responses to a maximally effective concentration of $(S)$ - 5-fluorowillardiine ( $8 \mathrm{~mm}, \sim 100$ times the $\mathrm{EC}_{50}$; Fig. 3) were smaller than those to kainate and other 5-halogenated willardiine derivatives (Fig. 2). To address the issue as to whether some willardiine derivatives act as genuine partial agonists after block of desensitization by ConA, we compared, in the same cell, the amplitude of responses to a maximally effective concentration of kainate $\left(1.2 \mathrm{~mm}, \sim 100\right.$ times the equilibrium $\left.\mathrm{EC}_{50}\right)$ with those to other agonists applied at concentrations sufficient to produce responses $>98 \%$ of maximum, as judged by prior analysis of dose-response curves (Fig. 3). The majority of agonists examined in this experiment $(5-\mathrm{Br}, 5-\mathrm{Cl}, 5-\mathrm{I}, 5-\mathrm{CN}$, and $5-\mathrm{NO}_{2}$ willardiine) all produced responses comparable in size to those evoked by kainate (Fig. 4); however, responses to 10 $\mathrm{mm}(S)$-willardiine $(15.4 \pm 5.0 \%$ of the maximum response to kainate), $3 \mathrm{~mm}(S)-5$-methylwillardiine $(51.0 \pm 10.6 \%), 8$ or 10 $\mathrm{mm}(S)$-5-fluorowillardiine $(81.0 \pm 8.9 \%)$, and 20 or $30 \mathrm{~mm}$ $(R, S)$-AMPA $(64.7 \pm 8.1 \%)$ were significantly smaller than responses to kainate, suggesting partial agonist activity. We were unable to construct a complete dose-response curve for $(S)$ willardiine due to low potency and limited solubility, but estimate that the $\mathrm{EC}_{50}$ must exceed $1 \mathrm{~mm}$. The low amplitude of responses to $10 \mathrm{~mm}(S)$-willardiinc suggests that it also is a partial agonist.

\section{Deactivation kinetics in DRG versus hippocampal neurons}

The kinetics of deactivation for ligand-gated ion channels, recorded by rapid removal of agonist, will be strongly influenced by agonist affinity if the dissociation rate constant for agonist binding is slow relative to the closing rate constant for ion channel gating. Deactivation responses for ligand-gated ion channels can also be influenced by the delayed opening of receptor channel complexes trapped in agonist-bound desensitized states (e.g., Lester and Jahr, 1992; Patneau et al., 1992). To avoid this complication, our experiments were performed under conditions that blocked desensitization: DRG neurons were treated with ConA (Fig. 2), while for hippocampal neurons agonist responses were recorded in the presence of $100 \mu \mathrm{M}$ cyclothiazide, a drug previously shown to abolish sclcctivcly descnsitization at AMPA-preferring glutamate receptors (Partin et al., 1993; Patneau et al., 1993; Wong and Mayer, 1993; Yamada and Tang, 1993). For both cell types agonists were applied at doses producing similar amplitude responses, approximately 100 times the $\mathrm{EC}_{50}$ for $\mathrm{DRG}$ neurons, and $0.3-5$ times the equilibrium $\mathrm{EC}_{50}$ for hippocampal neurons. Figure 5 shows superimposed traces of tail currents recorded following termination of the application of kainate, $(S)$-5-nitrowillardiine, and the four halogenated $(S)$-willardiine derivatives. For DRG and hippocampal neurons the rate of decay of the tail current varied with agonist potency (Fig. 5) and, in DRG neurons, followed the sequence fluoro $>$ kainate $>$ nitro $>$ chloro $>$ bromo $>$ iodo; in hippocampal neurons the order for halogenated willardiines was reversed, the sequence being kainate $>$ iodo $>$ bromo $>$ chloro $>$ nitro $>$ fluoro. In both preparations the rank order of the rate of decay of tail current responses is the reverse of the rank order for potency determined from analysis of equilibrium dose-response curves, suggesting that the use of cyclothiazide and ConA did not interfere with measurement of structureactivity relationships for deactivation responses.

For both cell types the tail current kinetics recorded following a switch to agonist-free solution were best described by the sum of two exponentials (Fig. $5 A, C$ ). In DRG neurons the time constant and relative amplitude of the major $\left(\tau_{1}\right)$ and minor $\left(\tau_{2}\right)$ 
A

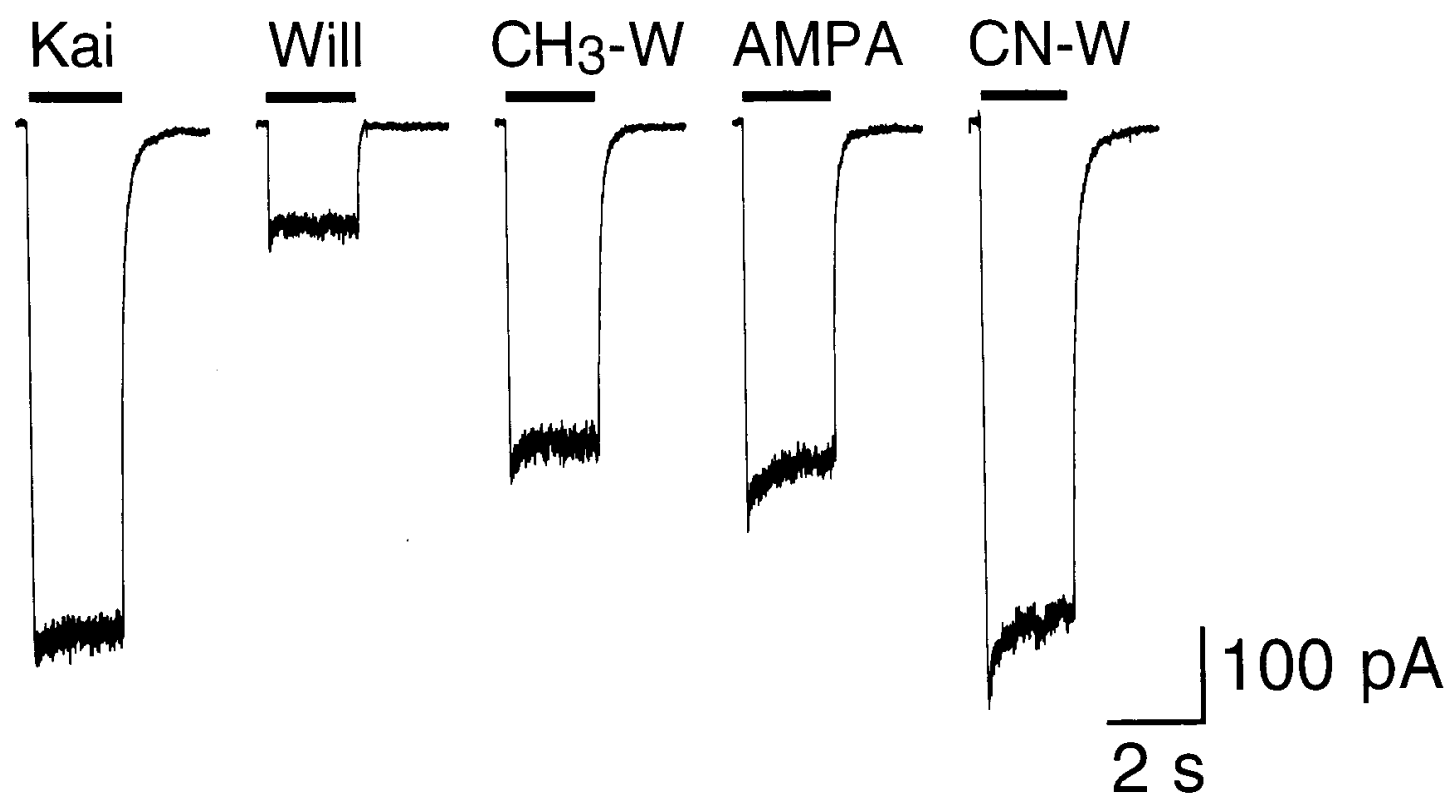

B

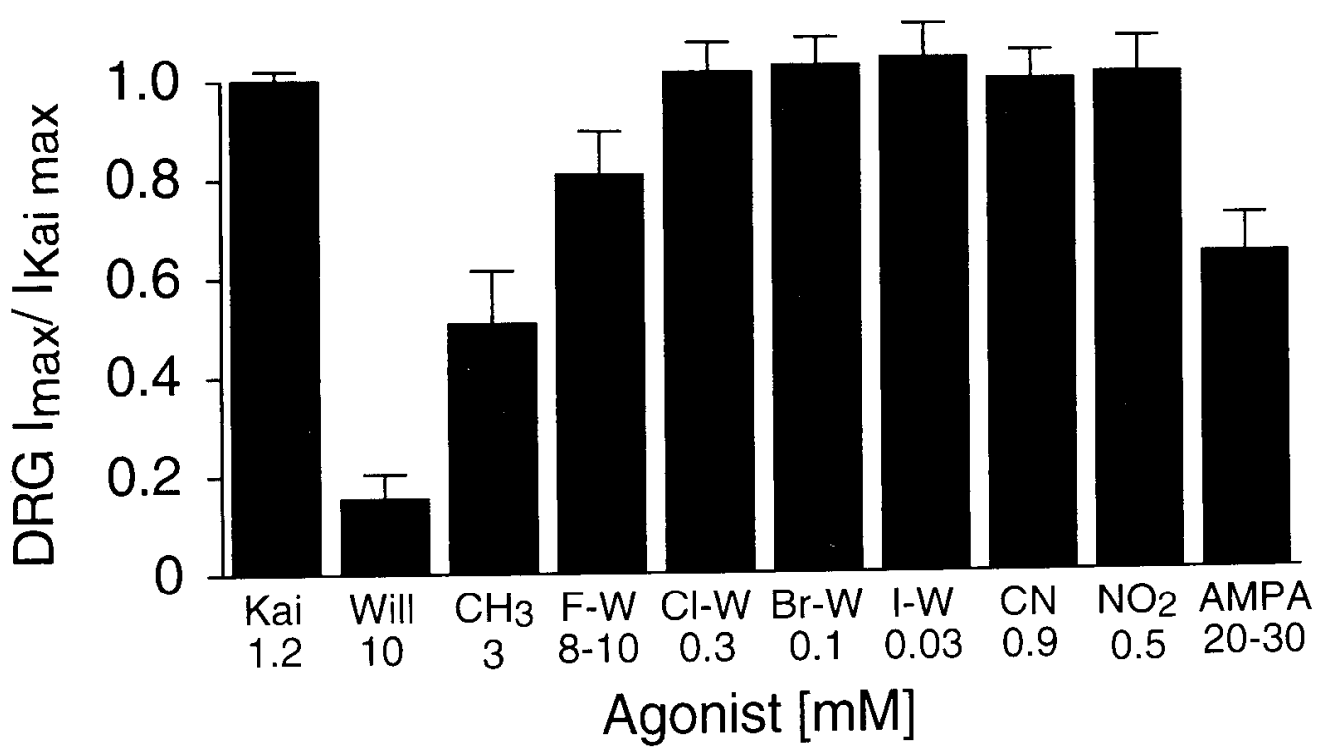

Figure 4. Partial agonist responses in DRG neurons. $A$ shows responses to 1.2 mM kainate $($ Kai $), 10$ mm $(S)$-willardiine $(W i l l)$, 3 mM $(S)$-5methylwillardiine $\left(\mathrm{CH}_{3}-W\right), 20 \mathrm{mM}(R, S)$-AMPA, and $900 \mu \mathrm{M}(S)$-5-cyanowillardiine $(C N$-W) recorded from the same DRG neuron after pretrcatment with ConA $(300 \mu \mathrm{g} / \mathrm{ml})$ for $5 \mathrm{~min} . B$ plots the peak amplitude of responses to application of various agonists (concentrations $\sim 100$ times $\left.\mathrm{EC}_{50}\right)$, normalized with respect to responses evoked by kainate. Note that even after treatment with $\mathrm{ConA}, \mathrm{CH}, \mathrm{W}, \mathrm{F}-\mathrm{W}$, and $(R, S)-\mathrm{AMPA}$ appear to act as partial agonists, while responses to the other 5-substituted willardiines are similar in amplitude to those evoked by kainate. Responses to $10 \mathrm{mM}(S)$-willardiine were much smaller than those to all other agonists, but since we were unable to estimate the $\mathrm{EC}_{50}$ for $(S)$-willardiine it is not possible to state with certainty whether this reflects the application of a submaximally effective concentration of a full agonist, or the response to a genuine partial agonist.

components of tail current decay followed the sequence $\mathrm{I}\left[\tau_{1}=\right.$ $4.49 \pm 0.69 \sec (75 \pm 7 \%), \tau_{2}=0.82 \pm 0.28 \sec (5$ observations, 5 cells $)]>\operatorname{Br}\left[\tau_{1}=1.51 \pm 0.15 \sec (65 \pm 5 \%), \tau_{2}=0.31 \pm\right.$ $0.06 \mathrm{sec}(5$ observations, 4 cells $)]>\mathrm{Cl}\left[\tau_{1}=173 \pm 29 \mathrm{msec}\right.$ $(79 \pm 7 \%), \tau_{2}=687 \pm 65 \mathrm{msec}(3$ observations, 3 cells $\left.)\right]>\mathrm{NO}_{2}$ $\left[\tau_{1}=137 \pm 15 \mathrm{msec}(89 \pm 5 \%), \tau_{2}=869 \pm 401 \mathrm{msec}(3\right.$ observations, 3 cells) $]>$ kainate $\left[\tau_{1}=69 \pm 10 \mathrm{msec}(73 \pm 6 \%)\right.$, $\tau_{2}=402 \pm 93 \mathrm{msec}(9$ observations, 5 cells $\left.)\right]>\mathrm{F}\left[\tau_{1}=44 \pm\right.$ $7 \mathrm{msec}(80 \pm 10 \%), \tau_{2}=391 \pm 110 \mathrm{msec}$ ( 4 observations, 4 cells)] (mean \pm SEM). Block of desensitization by ConA did 


\section{A DRG}

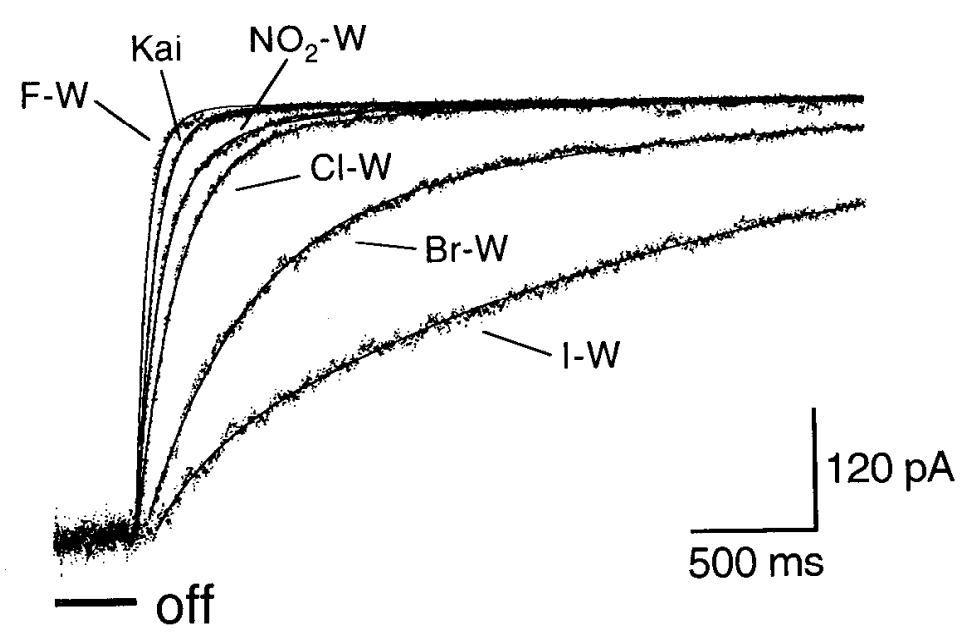

B

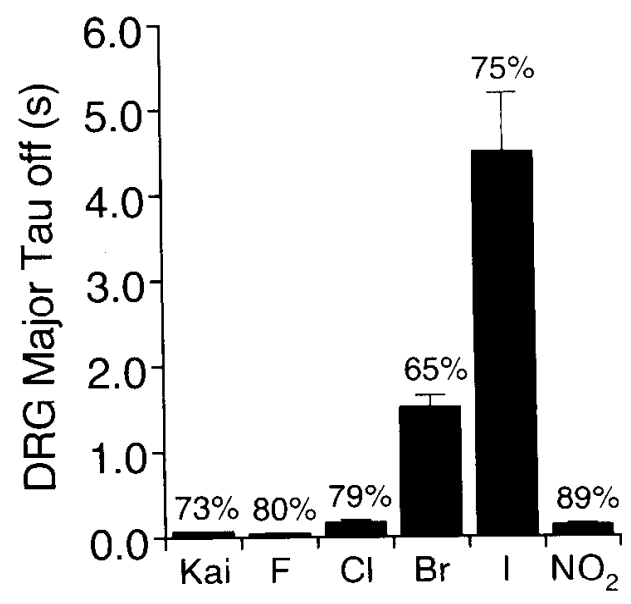

\section{Hippocampus}
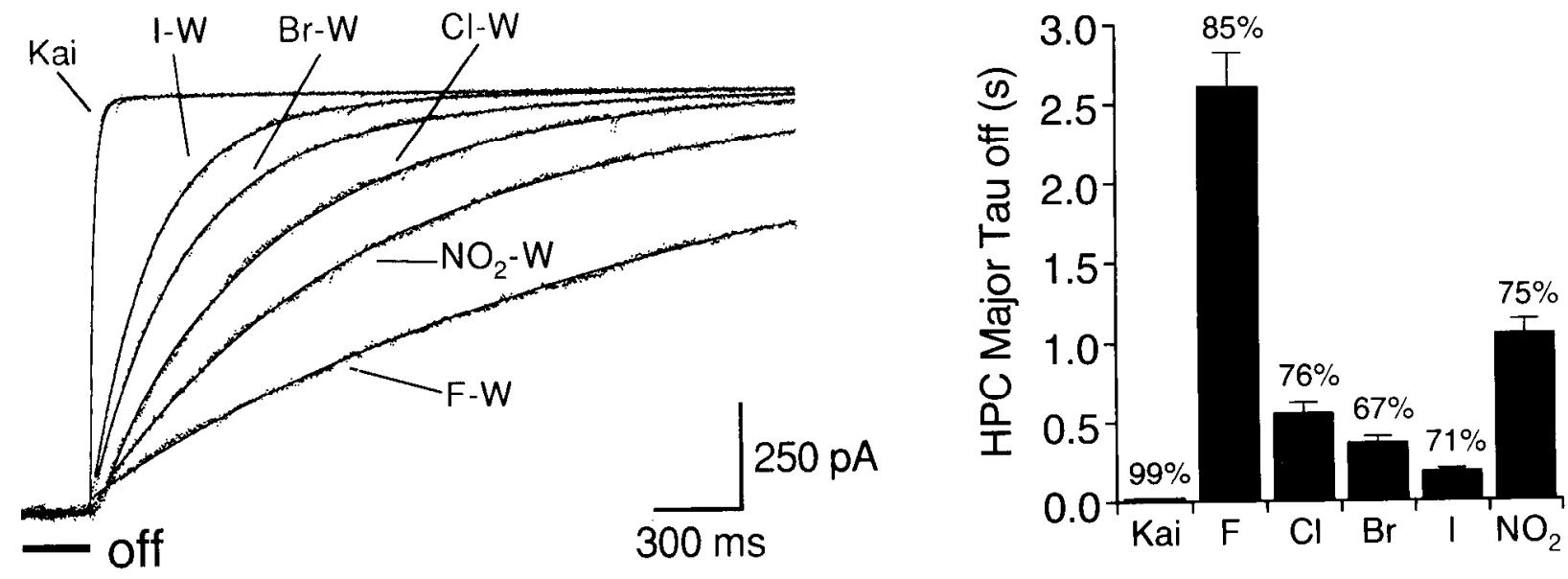

Figure 5. Deactivation kinetics vary with agonist potency. $A$ shows tail currents recorded from a single DRG neuron pretreated with ConA, in response to the removal of agonists applied at the following concentrations (solid bar below records): $30 \mu \mathrm{M}(S)-5$-iodowillardiine, $100 \mu \mathrm{M}(S)$-5bromowillardiine, $300 \mu \mathrm{M}(S)$-5-chlorowillardiine, $500 \mu \mathrm{M}(S)$-5-nitrowillardiine, $10 \mathrm{~mm}(S)$-5-fluorowillardiine, $1.2 \mathrm{~mm}$ kainate. Equilibrium responses recorded before the removal of agonist were scaled with respect to the amplitude of the response to kainate (scale factors: I-W and Br$\mathrm{W}, 1.3 ; \mathrm{Cl}-\mathrm{W}$ and $\left.\mathrm{NO}_{2}-\mathrm{W}, 1.4 ; \mathrm{F}-\mathrm{W}, 1.5\right)$. Lines drawn through the data points are least-squares fits of the sum of two exponentials. $B$ plots the mean time constant of deactivation for the exponential component of greater amplitude for experiments on three to five DRG neurons per agonist; numbers above the bar plots give the amplitude value for each component expressed as a percentage of the total decay. $C$ shows tail currents recorded in a hippocampal neuron in response to the removal of agonists applied at the following concentrations: $3 \mu \mathrm{M} \mathrm{F}-\mathrm{W}, 10 \mu \mathrm{M} \mathrm{NO} \mathrm{N}_{2}-\mathrm{W}, 4 \mu \mathrm{M}$ $\mathrm{Cl}-\mathrm{W}, 14 \mu \mathrm{M} \mathrm{Br}-\mathrm{W}, 20 \mu \mathrm{M} \mathrm{I}-\mathrm{W}, 50 \mu \mathrm{M}$ kainate; $100 \mu \mathrm{M}$ cyclothiazide was present continuously to block desensitization. Responses were scaled with respect to the amplitude of the response to kainate (scale factors: $\mathrm{Br}-\mathrm{W}, 1.14 ; \mathrm{Cl}-\mathrm{W}$ and $\mathrm{NO}_{2}-\mathrm{W}, 1.25 ; \mathrm{F}-\mathrm{W}, 1.3$ ). Lines drawn through the data points are least-squares fits of the sum of two exponentials; note that the deactivation kinetics for the majority of agonists differ from those for DRG neurons. $D$ plots the mean time constant of deactivation for the exponential component of greater amplitude for experiments on four to six hippocampal neurons per agonist with amplitudes expressed as in $B$.

not substantially alter deactivation kinetics in $\mathrm{DKG}$ neurons, since in four cells the time constants of deactivation for responses to kainate were similar before $\left(\tau_{1}=43 \pm 5 \mathrm{mscc}, 66\right.$ $\left.\pm 11 \% ; \tau_{2}=267 \pm 47 \mathrm{msec}\right)$ and after treatment with lectin $\left(\tau_{1}\right.$ $=52+6$ msec, $65 \pm 10 \% ; \tau_{2}=259 \pm 70$ msec; mean \pm SEM $)$.

In hippocampal neurons the kinetics of tail current decay followed the sequence $\mathrm{F}\left[\tau_{1}=2.6 \pm 0.22 \mathrm{sec}(85 \pm 8 \%), \tau_{2}=\right.$ $0.52 \pm 0.14 \mathrm{sec}(5$ observations, 3 cells $)]>\mathrm{NO}_{2}\left[\tau_{1}=1.05 \pm\right.$ $0.09 \mathrm{sec}(75 \pm 7 \%), \tau_{2}=1.73 \pm 0.51 \mathrm{sec}(8$ observations, 5 cells $)]>\mathrm{Cl}\left[\tau_{1}=0.55 \pm 0.07 \mathrm{sec}(76 \pm 5 \%), \tau_{2}=0.97 \pm 0.25\right.$ $\sec (8$ observations, 5 cells $)]>\operatorname{Br}\left[\tau_{1}=0.36 \pm 0.04 \sec (67 \pm\right.$
$6 \%), \tau_{2}=0.57 \pm 0.12 \mathrm{sec}(8$ observations, 5 cells $\left.)\right]>\mathrm{I}\left[\tau_{1}=\right.$ $188 \pm 18 \mathrm{msec}(71 \pm 5 \%), \tau_{2}=0.45 \pm 0.03 \mathrm{sec}$ ( 7 observations, 5 cclls $)]>$ kainate $\left[\tau_{1}=22 \pm 1.0 \mathrm{msec}(99 \% \pm 0.5 \%), \tau_{2}=0.84\right.$ $\pm 0.24 \mathrm{sec}$ ( 8 observations, 5 cells)] (mean $\pm \mathrm{SEM}$ ). The time constants for $(S)$-5-fluorowillardiine are slower than previously measured (Patneau et al., 1992), reflecting a slowing by cyclothiazide of deactivation kinetics for agonist responses at AMPApreferring glutamate receptors (Patneau et al., 1993). This did not interfere with the interpretation of our experiments, which were designed to measure the rank order of the kinetics of deactivation for various willardiines in hippocampal neurons, in- 
dependent of the component due to recovery from desensitization; as expected, there was exact agreement between the agonist rank order for the deactivation responses and equilibrium potency sequences.

\section{Kinetics of onset of desensitization are faster in hippocampal than in DRG neurons}

All of the 5-substituted willardiines tested, as well as kainate and AMPA, evoked profound desensitization when applied to DRG neurons at maximally effective doses $(\sim 100$ times the $\mathrm{EC}_{50}$ ); with the exception of responses to kainate, the same series of agonists also evoked strong desensitization in hippocampal neurons (Figs. 1, 6). The kinetics of onset of desensitization of responses to willardiines in DRG and hippocampal neurons showed substantial differences between the two cell types, and for all agonists examined were much faster for hippocampal than for DRG neurons (Fig. 6). With agonist applications lasting $2 \mathrm{sec}$, the onset of desensitization in DRG neurons was well fit by the sum of two exponentials, the time constants of which differed greater than 10 -fold, with the slow component accounting for approximately $50 \%$ of the amplitude of desensitization. For the series of 5-halogenated willardiines, which produced on average $88.4 \pm 6.4 \%$ desensitization at $2 \mathrm{sec}$, the time constants of onset of desensitization were (mean \pm SEM), for $F, \tau_{1}=37$ $\pm 8.3 \mathrm{msec}(40 \pm 6 \%), \tau_{2}=585 \pm 41 \mathrm{msec}(60 \pm 6 \%), 16$ cells; $\mathrm{Cl}, \tau_{1}=55 \pm 7.2 \mathrm{msec}(47 \pm 4 \%), \tau_{2}=508 \pm 33 \mathrm{msec}(53 \pm$ $4 \%), 20$ cells; $\mathrm{Br}, \tau_{1}=58 \pm 12 \mathrm{msec}(51 \pm 4 \%), \tau_{2}=542 \pm 48$ msec $(49 \pm 4 \%), 14$ cells; $I, \tau_{1}=64 \pm 11 \mathrm{msec}(45 \pm 5 \%), \tau_{2}$ $=527 \pm 32 \mathrm{msec}(55 \pm 5 \%), 13$ cells. For responses to kainate, which produced on average $54.6 \pm 9.1 \%$ desensitization at 2 sec, desensitization occurred with comparable kinetics: $\tau_{1}=61$ $\pm 5 \mathrm{msec}(31 \pm 4 \%), \tau_{2}=695 \pm 47 \mathrm{msec}(69 \pm 4 \%), 16$ cells.

Although desensitization in DRG neurons produced by $5-\mathrm{F}$, $5-\mathrm{Br}, 5-\mathrm{I}$, and 5- $\mathrm{NO}_{2}$ willardiine applied for $2 \mathrm{sec}$ averaged 88.6 $\pm 6.1 \%$ (19 cells), when these agonists were applied to DRG neurons for $15 \mathrm{sec}$ desensitization was effectively complete (Fig. $6 E$ ), reaching $98.4 \pm 1.2 \%$ for $8 \mathrm{~mm}(S)$-5-fluorowillardiine (11 observations, 5 cells), $99.1 \pm 2.0 \%$ for $200 \mu \mathrm{M}(S)$-5-bromowillardiine (5 observations, 3 cells), $99.5 \pm 0.5 \%$ for $15 \mu \mathrm{M}(S)$ 5 -iodowillardiine ( 3 observations, 3 cells), and $97.7 \pm 0.2 \%$ for 1 mм (S)-5-nitrowillardiine (3 observations, 2 cells); pronounced desensitization $(99 \%, 2$ cells) was also evoked by 30 $\mathrm{mM}(R, S)$-AMPA. In contrast, when $1.5 \mathrm{~mm}$ kainate was applied for $30 \mathrm{sec}$, desensitization was incomplete, reaching only 92.5 $\pm 2.5 \%$ ( 7 observations, 5 cells). Long agonist applications revealed a small-amplitude, slow component of onset of desensitization not well resolved with bricfer applications, such that the sum of three exponentials was required to describe adequately the kinetics of onset of desensitization; for 5-substituted willardiines $\tau_{3}$, the third time constant, had a value and relative amplitude of, for $\mathrm{F}, 2.7 \pm 0.7 \mathrm{sec}(16 \pm 7 \%), 8$ observations, 4 cells; $\mathrm{Br}, 2.4 \pm 0.4 \sec (11 \pm 4 \%), 3$ observations, 2 cells; and I, $2.6 \pm 0.4 \mathrm{sec}(10 \pm 5 \%), 3$ observations, 3 cells. A similar value for $\tau_{3}, 3.1 \mathrm{sec}(13 \%)$, was obtained in one cell for AMPA, while for kainate the third time constant occurred with slower kinetics, $\tau_{3}=9.3 \pm 3.3 \mathrm{sec}$ ( 5 observations, 4 cells), and accounted for a larger component $(33 \pm 17 \%)$ of desensitization than observed for the other agonists examined. Our results are in reasonable agreement with those obtained by Huettner (1990), who observed complete desensitization for equilibrium responses to glutamate and quisqualate, but only $85-90 \%$ desensitization for responses to prolonged application of kainate.
In hippocampal neurons the onset of desensitization of responses to 5-halogenated willardiines applied at approximately 300 times the $\mathrm{EC}_{50}$ was also best fit by the sum of two exponentials, the time constants of which were faster than those for DRG neurons; as a result, desensitization in hippocampal neurons typically reached equilibrium within $100 \mathrm{msec}$, whereas in DRG neurons several seconds were required for willardiine responses to approach equilibrium. In addition the fast component of desensitization typically accounted for approximately $80 \%$ of the amplitude of desensitization in hippocampal neurons, versus only 50\% in DRG neurons (Fig. 6); also, different from DRG neurons, the degree of equilibrium desensitization evoked by willardiines in hippocampal neurons varied with agonist (Patneau et al., 1992), and was much greater for $(S)$-5fluorowillardiine than for (S)-5-bromowillardiine (Fig. $6 B$ ). The time constants of onset of desensitization in hippocampal neurons were, for $\mathrm{F}, \tau_{1}=11 \pm 0.15 \mathrm{msec}(79 \pm 2 \%), \tau_{3}=46 \pm 2$ msec $(21 \pm 6 \%), 4$ cells; $\mathrm{Cl}, \tau_{1}=11 \pm 1 \mathrm{msec}(82 \pm 2 \%), \tau_{2}=$ $45 \pm 6 \mathrm{msec}(18 \pm 4 \%), 9$ cells; $\mathrm{Br}, \tau_{1}=12 \pm 1 \mathrm{msec}(73 \pm$ $3 \%), \tau_{2}=46 \pm 6 \mathrm{msec}(27 \pm 4 \%), 9$ cells; I, $\tau_{1}=14 \pm 2 \mathrm{msec}$ $(77 \pm 6 \%), \tau_{2}=55 \pm 10 \mathrm{msec}(23 \pm 5 \%), 6$ cells. With wholecell recording, and the perfusion apparatus used in the present experiments, responses to kainate did not show desensitization in hippocampal neurons (but see Patneau et al., 1993, for a description of desensitization to kainate in hippocampal neurons recorded with more rapid perfusion techniques).

\section{Kinetics of recovery from desensitization}

To determine the time course of recovery from desensitization in DRG ncurons, two protocols were used that differed for agonists with fast versus slow recovery kinetics (Fig. 7). For $(S)$ 5-fluorowillardiine, which showed fast recovery, we used a twinpulse protocol (Fig. 7A) in which the interval between responses to a conditioning pulse of $500 \mu \mathrm{M}(S)$-5-fluorowillardiine and a subsequent test response to $150 \mu \mathrm{M}$ kainate was varied to assess the kinetics of recovery from desensitization. For $(S)$-5-bromowillardiine $(5 \mu \mathrm{M})$ and $(S)$-5-iodowillardiine (1 $\mu \mathrm{M})$, which showed slower recovery from desensitization, we used an envelope protocol in which $400 \mathrm{msec}$ test responses to kainate applied every $20 \mathrm{sec}$ were used to follow recovery from desensitization evoked by a single $2 \mathrm{sec}$ application of either of these willardiines (Fig. $7 C$ ). Recovery from desensitization measured using these protocols was fit by the sum of two exponentials, the time constants and relative amplitudes of which were agonist dependent (Fig. 7B,D). For (S)-5-fluorowillardiine $85 \pm 3.4 \%$ of recovery from desensitization occurred with a time constant of $3.9 \pm 0.2 \mathrm{sec}$ (mean $\pm \mathrm{SEM}, 4$ cells); the time constant of the second component was poorly defined, and varied widely from cell to cell. In contrast, for $(S)$-5-bromowillardiine $86.7 \pm$ $2.4 \%$ of recovery occurred with a time constant $\left(\tau_{\text {slow }}\right)$ of $160 \pm$ $15.6 \mathrm{sec}$, with the remainder accounted for by a component with faster kinetics, of time constant $\left(\tau_{\text {fast }}\right) 15 \pm 6.6 \mathrm{sec}$ (mean \pm SEM, 3 cells). Pooled data for $(S)$-5-fluorowillardiine and $(S)$ 5 -bromowillardiine are shown in Figure $7, B$ and $D$. For $(S)-5$ iodowillardiine ( 3 cells, data not shown), the time course of recovery from desensitization was even slower, with $\tau_{\text {fast }}=35.6$ $\pm 4.4 \mathrm{sec}(45.7 \pm 3.5 \%)$ and $\tau_{\text {slow }}=4.4 \pm 0.6 \mathrm{~min}(54.3 \pm$ $3.5 \%$ ). The rank order of the rate of recovery from desensitization in DRG neurons, fluoro $>$ bromo $>$ iodo, is the same as that for deactivation, and the reverse of that for agonist potency, iodo $>$ bromo $>$ fluoro; however, the kinetics of re- 


\section{A DRG}

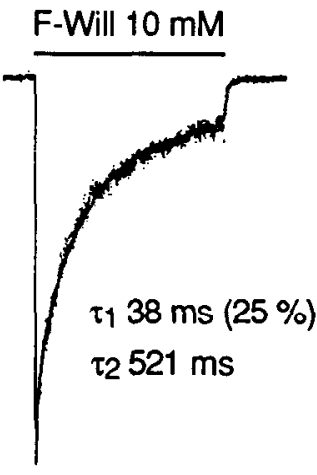

Br-Will $0.1 \mathrm{mM}$

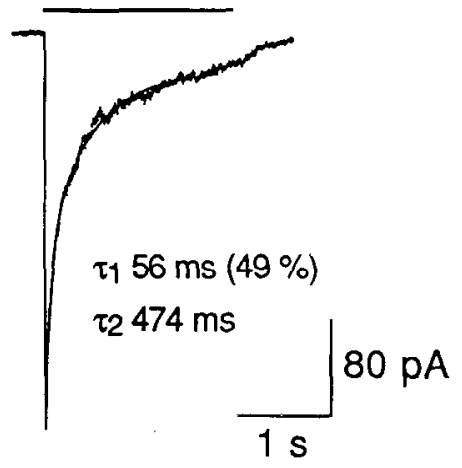

DRG $\mathrm{HPC}$

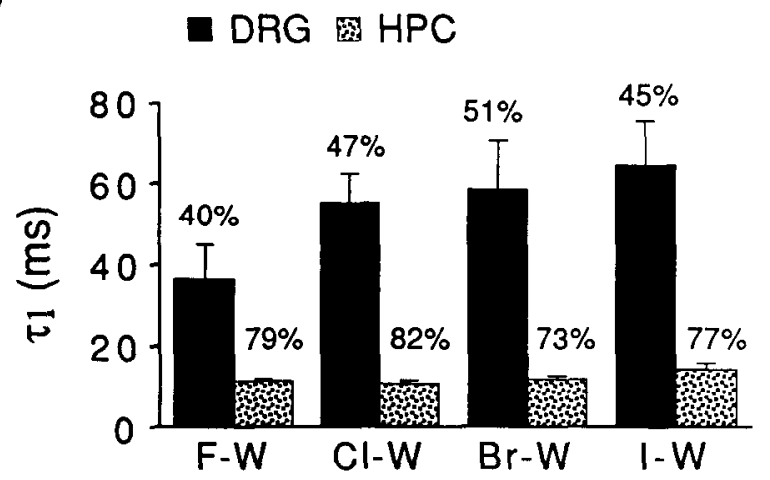

\section{B Hippocampus}

F-Will $1 \mathrm{mM}$

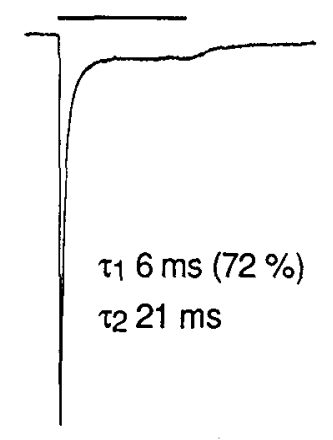

Br-Will $2.7 \mathrm{mM}$

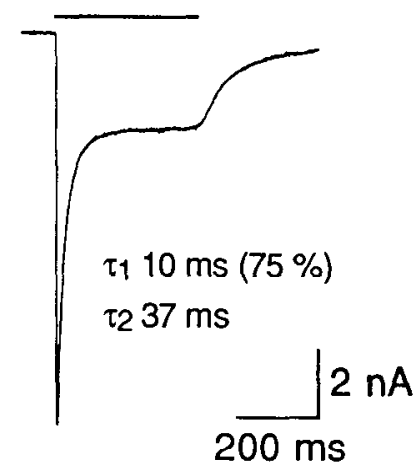

C

D

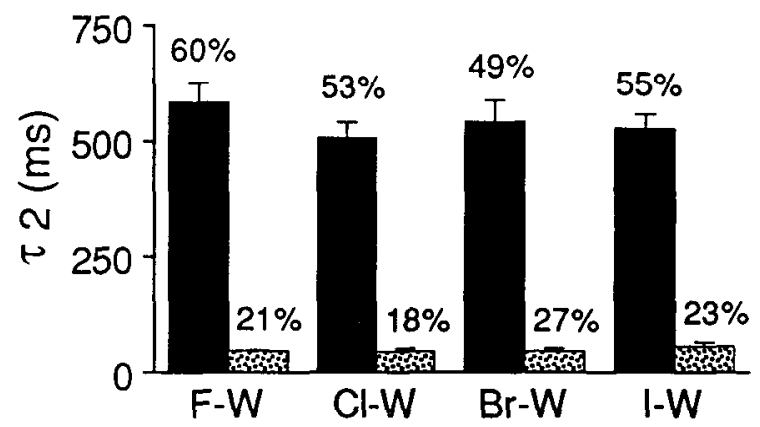

\section{E DRG}

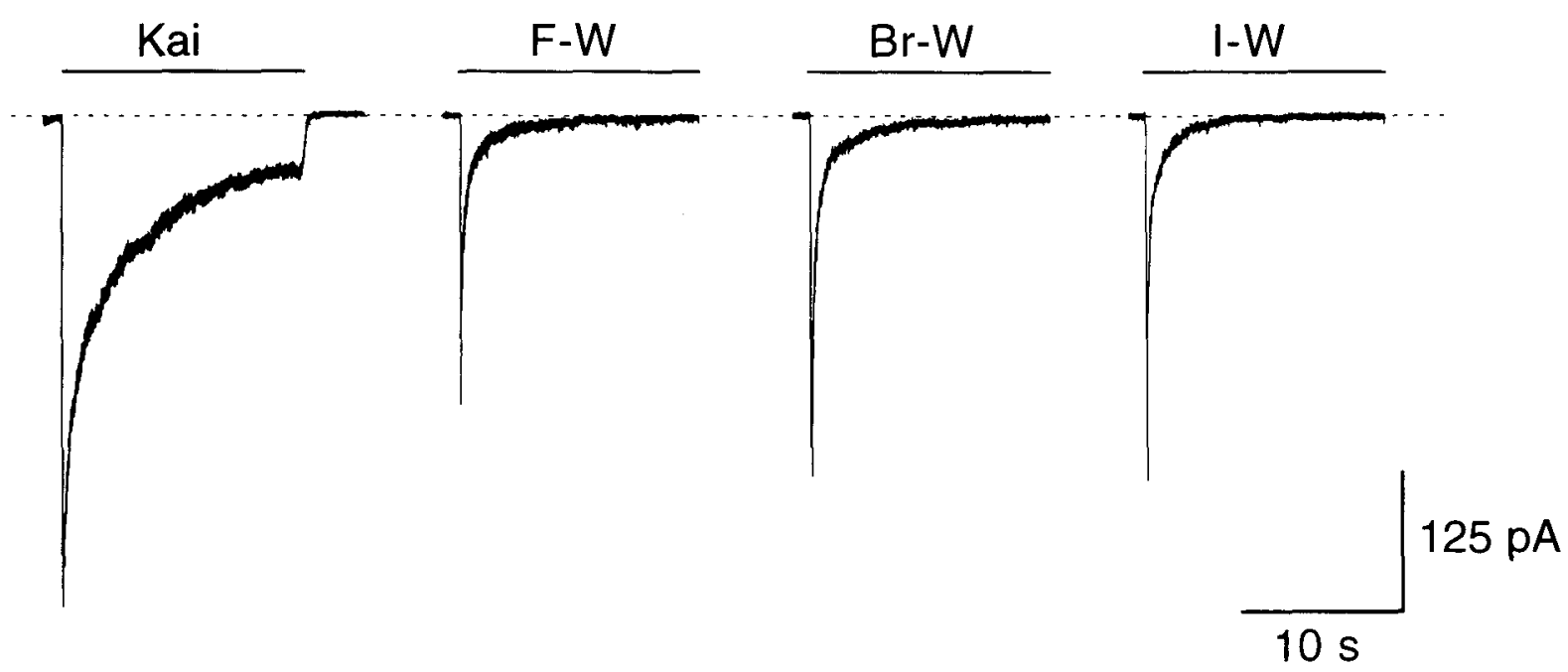

Figure 6. The kinetics of onset of desensitization of responses to willardiines differ in DRG versus hippocampal neurons. $A$ shows responses of a DRG neuron to $10 \mathrm{~mm}(S)$-5-fluorowillardiine and $0.1 \mathrm{~mm}(S)$-5-bromowillardiine; lines drawn through the data points during the onset of desensitization are least-squares fits of the sum of two exponentials the time constants of which are indicated adjacent to each record. $B$ shows similar responses to $1 \mathrm{mM} \mathrm{F-W}$ and $2.7 \mathrm{~mm} \mathrm{Br-W}$ recorded from a hippocampal neuron; note the faster time scale. $C$ and $D$ plot the time constants for the fast $\left(C, \tau_{1}\right)$ and slow $\left(D, \tau_{2}\right)$ components of onset of desensitization for pooled responses recorded from 13-20 cells per agonist in DRG neurons and 4-7 cells per agonist for hippocampal neurons; numbers above the bar plots give the relative amplitude of each component expressed as a percentage of the total decay. CI-W and I-W were applied at 30 and $300 \mu \mathrm{M}$ for DRG neurons, and at 2 and $6 \mathrm{mM}$ for hippocampal neurons. $E$ shows responses of a DRG neuron to prolonged applications $(15 \mathrm{sec}$ ) of $1.5 \mathrm{~mm}$ kainate, $8 \mathrm{mM} \mathrm{F}-\mathrm{W}, 600 \mu \mathrm{M} \mathrm{Br}-\mathrm{W}, 45 \mu \mathrm{M} \mathrm{I}-\mathrm{W}$; note that the response to these willardiines, but not to kainate, shows essentially complete desensitization. Lines drawn through the data points during the onset of desensitization are least-squares fits of the sum of three exponentials. Data for hippocampal neurons in $B-D$ are previously unpublished results from Patneau et al. (1992). 
A

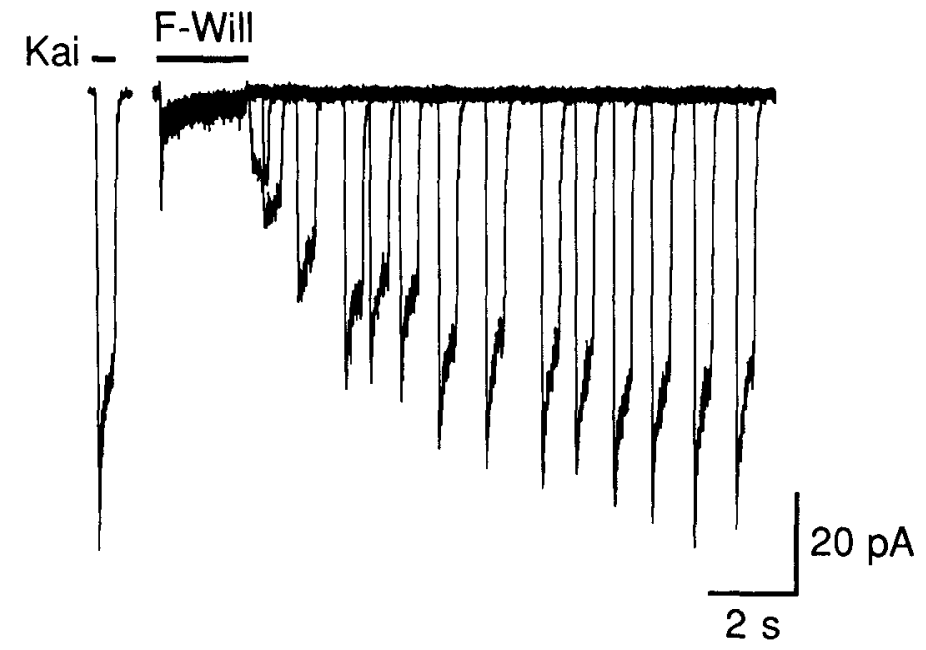

B
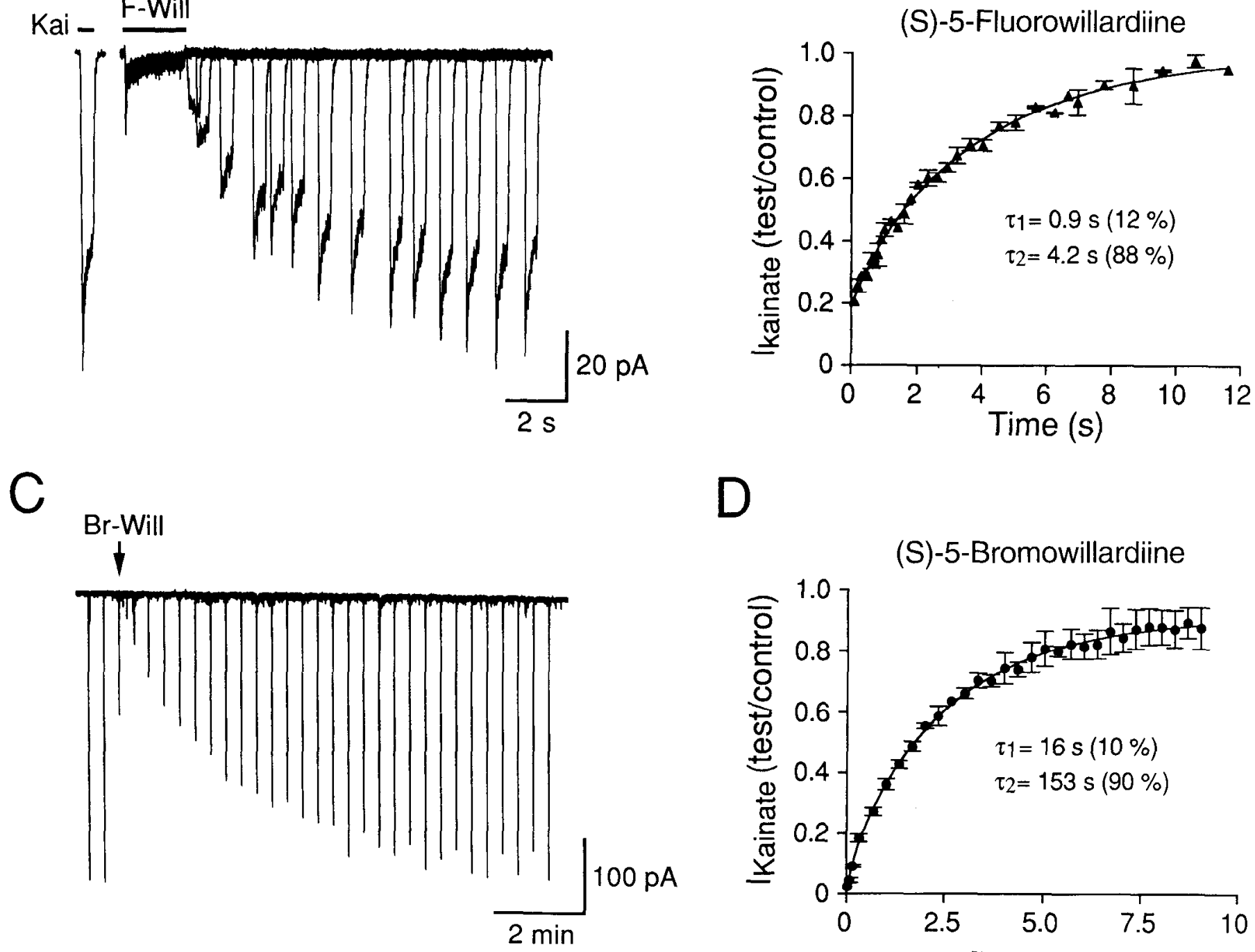

D

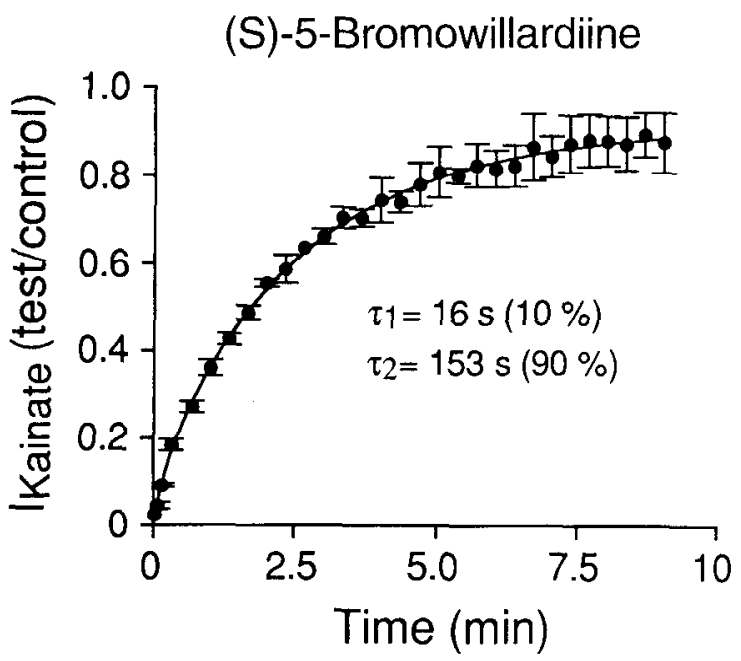

Figure 7. The kinctics of recovery from desensitization in DRG ncurons vary with agonist potency. $A$ shows twin-pulse cxperiments to detcrmine the time course of recovery from desensitization of test responses to $150 \mu \mathrm{M}$ kainate applied for $400 \mathrm{msec}$, following a 2 sec exposure to $500 \mu \mathrm{M}$ $(S)$-5-fluorowillardiine $(F$-Will); the records show 14 superimposed responses to F-Will, with the interval between the test application of kainate and the prior application of $F$-Will progressively increased. $B$ plots the peak amplitude of the test response to kainate normalized with respect to control, as a function of the interval between the end of the application of F-Will and the beginning of the test response to kainate. The data points show pooled values (mean \pm SEM) from four cells fitted with the sum of two exponentials, of time constants $\tau_{1}=0.9 \mathrm{sec}(12 \%)$ and $\tau_{2}=4.2 \mathrm{sec}$ $(88 \%)$. $C$ shows a chart record of responses to $150 \mu \mathrm{m}$ kainate applied for $400 \mathrm{msec}$ every $20 \mathrm{sec}$, interleaved with the response to a single 2 sec application of $5 \mu \mathrm{M}(S)$-5-bromowillardiine $(B r-W i l l)$. D plots the peak amplitude of the response to kainate, normalized to control, as a function of time following the end of the application of $\mathrm{Br}$-Will; data points show pooled values (mean $\pm \mathrm{SEM}$ ) from three cells fitted with the sum of two exponentials of time constants $\tau_{1}=16 \sec (10 \%)$ and $\tau_{2}=153 \mathrm{sec}(90 \%)$.

covery from desensitization were much slower than those for deactivation (compare Fig. 5).

In hippocampal neurons recovery from desensitization evoked by willardiines, especially $(S)$-5-iodowillardiine, occurred too rapidly for accurate analysis using the protocols described above. As an alternative approach we took advantagi of the fact that in hippocampal neurons responses to kainate show a large-amplitude nondesensitizing component, such that the kinetics of the rate of increase in amplitude of the response to kainate, following a direct switch from a desensitizing agonist to kainate, would be expected to reflect the kinetics of recovery from de- sensitization (e.g., Patneau and Mayer, 1991). Such experiments were performed using $10 \mu \mathrm{M}(S)$-5-fluorowillardiine (Fig. 8A) and $1 \mathrm{mM}(S)$-5-iodowillardiine (Fig. $8 B$ ) to cross-desensitize test responses evoked by subsequent application of $1.5 \mathrm{~mm}$ kainate. The test response to kainate following the application of $(S)$-5-fluorowillardiine consisted of an initial rapid increase in current, of rise time $12.9 \pm 1.5 \mathrm{msec}$ (amplitude, $12.8 \pm 1.9 \%$ of the control response to kainate, mean \pm SEM, 7 cells), followed by a slow relaxation due to recovery from desensitization that was best fit by the sum of two exponentials of time constants $\tau_{1}=240 \pm 48 \mathrm{msec}(43 \pm 11 \%)$ and $\tau_{2}=1.57 \pm 0.16 \mathrm{sec}(57$ 
$\pm 11 \%$ ). The initial rapid response is due to activation by kainate of receptors that have not bound fluorowillardiine, since at 10 $\mu \mathbf{M}$ responses to this agonist are submaximal.

For $1 \mathrm{~mm}(S)$-5-iodowillardiine there was an initial rapid decrease in current on switching to $1.5 \mathrm{~mm}$ kainate [10-90\% decay time, $27.9 \pm 1.8 \mathrm{msec}$, maximum decrease to $90.9 \pm$ $3.4 \%$ of the equilibrium response to $(S)$-5-iodowillardiine], most likely due to deactivation of the response to $(S)$-5-iodowillardiine occurring more rapidly than subsequent recovery from desensitization, which was well described by a single exponential function of time constant $167 \pm 8 \mathrm{msec}$ (mean $\pm \mathrm{SEM}, 9$ observations, 4 cells). The rank order of the rate of recovery from desensitization in hippocampal neurons, fluoro $>$ iodo, is the reverse of that observed in DRG neurons, for which recovery from desensitization evoked by $(S)$-5-iodowillardiine proceeds much slower than that for $(S)$-5-fluorowillardiine. Because $(S)$ 5 -iodowillardiine was applied at a close to saturating concentration ( $1 \mathrm{~mm}$ ) there was no initial rapid increase in current on application of kainate (Fig. $8 B$ ), in contrast to results obtained with a lower, $10 \mu \mathrm{M}$ concentration of $(S)$-5-fluorowillardiine (Fig. 8A). Also, as expected from measurement of the ratio of the peak to steady state current for responses to maximally effective concentrations of willardiines (e.g., Fig. 1 and Patneau et al., 1992) the degree of desensitization of the response to kainate (defined as the amplitude of the current at the start of the slow relaxation divided by the current at the end of the relaxation of the test response to kainate) was stronger for 10 $\mu \mathrm{M}(S)$-5-fluorowillardiine $(66.3 \pm 5.4 \%)$ than for $1 \mathrm{~mm}(S)-5$ iodowillardiine $(29.5 \pm 2.6 \%)$.

\section{Discussion}

The recent isolation of at present 14 subunits for mammalian CNS glutamate receptor-operated ion channels, and their classification based on functional properties and sequence homology into AMPA-, kainate-, and NMDA-preferring families (for review, see Hollmann and Heinemann, 1993), has largely confirmed the original classification scheme proposed by Watkins and Evans (1981), with the exception that it is now believed that each family consists of a number of as yet poorly characterized subtypes generated by assembly of various subunits in unknown combinations and stoichiometries. Two additional subunits with sequence homology to glutamate receptors have also been identified ( $\delta-1$ and $\delta-2)$ but because when expressed they do not generate glutamate binding sites or agonist-activated currents, or modify the functional properties of other glutamate receptor subunits, their relationship to other members of the glutamate receptor gene family remains uncertain (Yamazaki et al., 1992; Lomeli et al., 1993). Despite this recent explosion in knowledge, the identification of CNS preparations expressing different populations of native glutamate receptor subtypes is still at a primitive stage. DRG and hippocampal neurons represent two cell populations, which although intrinsically heterogeneous, express functionally distinct subtypes of non-NMDA receptor with which it is possible to examine the functional properties and molecular composition of native glutamate receptors corresponding to the broad classes of kainate- and AMPA-preferring subtypes, respectively. Although the subunits used to assemble glutamate receptors in these tissues are still unknown, studies with antibodies, and the analysis of mRNA levels within individual cell types, will eventually provide a molecular counterpart to the functional results described here; as a working hypothesis we assume that subunits from the
AMPA- and kainate-preferring receptor families do not crossassemble, and that it is unlikely that DRG neurons express a significant number of functionally active AMPA-preferring receptors while hippocampal neurons are unlikely to express a significant number of functionally active kainate-preferring receptors. Some of the evidence for this is discussed below, and in recent reports (Partin et al., 1993; Wong and Mayer, 1993).

\section{Agonist selectivity for kainate-versus AMPA-preferring glutamate receptors}

Sequence analysis of glutamate receptor subunits reveals a series of 10 amino acid residues in the $\mathrm{N}$-terminal extracellular domain that is conserved in all subunits identified to date. These sequences also occur in the Escherichia coli periplasmic glutamine binding protein (Nohno et al., 1986; Nakanishi et al., 1990), and it has been proposed that they are good candidates for amino acid residues likely to contribute to the glutamate binding site (Nakanishi et al., 1986; Hollman and Heinemann, 1993), suggesting common features in the agonist recognition site of different glutamate receptor subtypes. Despite this, there is a wealth of evidence for substantial differences in the relative affinity of agonists and antagonists for NMDA versus nonNMDA receptors (Collingridge and Lester, 1989; Patneau and Mayer, 1990; Watkins et al., 1990). The results of the present study provide new information concerning possible molecular mechanisms underlying similar selectivity for agonist action at AMPA- versus kainate-preferring receptors. At present, no antagonists have been developed to discriminate between AMPAversus kainate-preferring receptors, but the results of our study give clues to differences in the ligand-binding properties of these receptors that might be exploited in the future design of selective antagonists.

All of thc agonists examined in this study, including $(R, S)$ AMPA, kainate, $(S)$-willardiine and its 5-substituted derivatives, produced responses at both kainate-preferring receptors in DRG neurons, as well as at AMPA-preferring receptors in hippocampal neurons; however, in DRG neurons the loweraffinity agonists AMPA, 5-fluorowillardiine, 5-methylwillardiine, and probably willardiine itself, appear to act as partial agonists. For the majority of the agonists examined there were substantial differences in relative affinity for DRG versus hippocampal neurons. Analysis of the response of AMPA-preferring subunits expressed in oocytes and HEK 293 cells has clearly established that kainate acts as an agonist at AMPA-preferring receptors (Boulter et al., 1990; Keinänen et al., 1990), but it is less clear whether AMPA acts as a full agonist at kainate-preferring receptors. Receptors generated by coexpression of the kainatepreferring subunits GluR-6 plus KA-2 (Herb et al., 1992) also referred to as $\beta-2$ and $\gamma-2$ (Sakimura ct al., 1992), but not by expression of GluR-6 alone, show only weak responses to AMPA. For the kainate-preferring subunit GluR-5-2a(Q) (Sommer et al., 1992) AMPA acts as a low-affinity agonist $\left(\mathrm{EC}_{50} \sim 3 \mathrm{mM}\right)$; however, because responses to AMPA concentrations greater than $3 \mathrm{~mm}$ were not examined it is unclear whether AMPA can act as a full agonist at homomeric GluR-5 receptors. That responses to AMPA in DRG neurons are due to activation of kainate-preferring and not AMPA-preferring receptors is suggested by the difference in $\mathrm{EC}_{50}$ values for AMPA in the two tissues (DRG, $261 \mu \mathrm{M}$, vs hippocampus, $11 \mu \mathrm{M}$ ), and by our observation that desensitization of responses to AMPA in DRG neurons is strongly attenuated by ConA but unaffected by cyclothiazide. In contrast, for hippocampal neurons cyclothiazide 
A
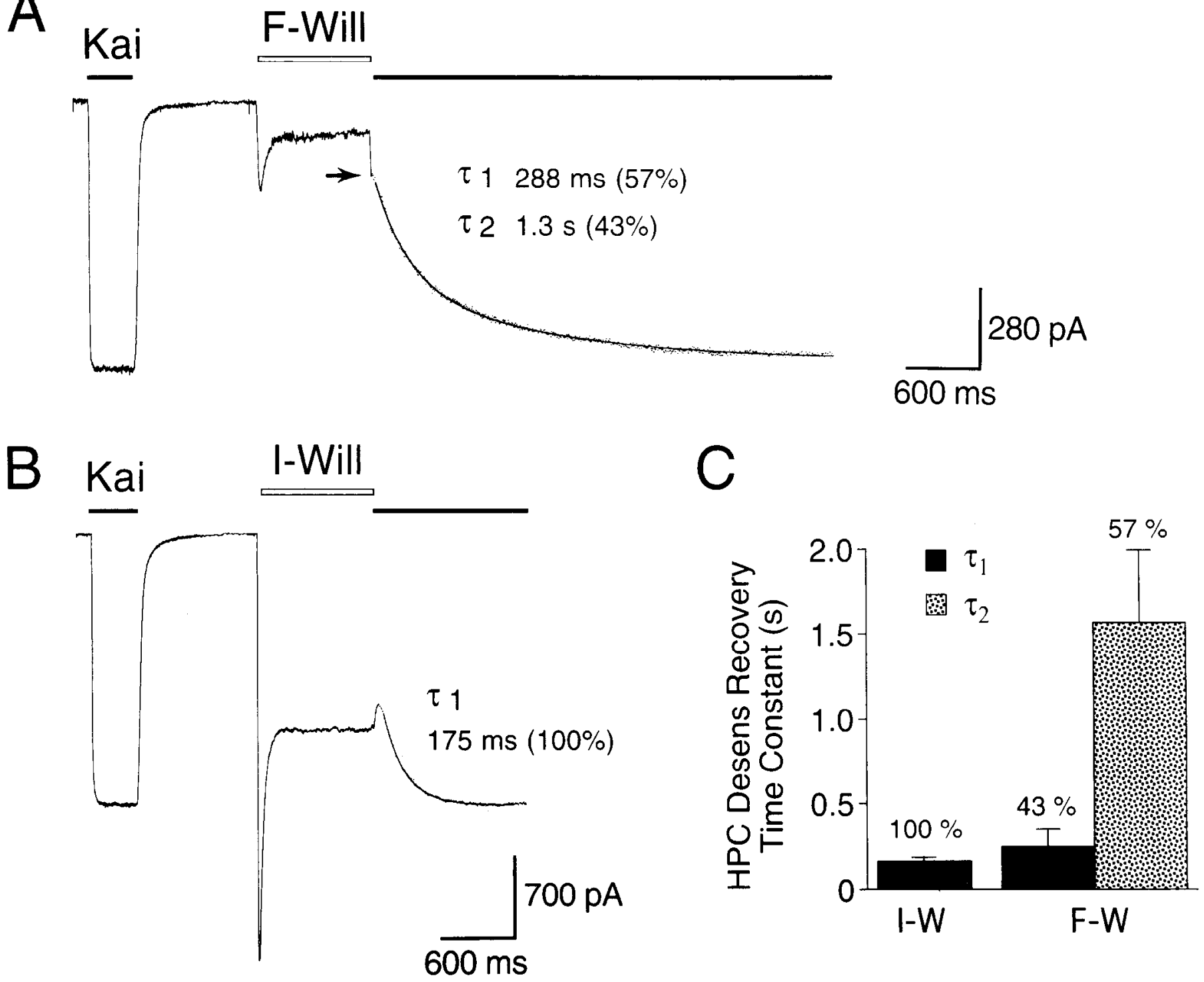

Figure 8. Responses to kainate in hippocampal neurons show rapid recovery from desensitization evoked by willardiines. $A$ and $B$ show a control response to $1.5 \mathrm{~mm}$ kainate, the response to $1 \mathrm{sec}$ application of $10 \mu \mathrm{M}$ F-Will $(A)$ or $1 \mathrm{~mm}$ I-Will followed immediately by the application of 1.5 mM kainate $(B)$. The kinetics of recovery from cross-desensitization to F-Will show an initial fast component (arrow), followed by a relaxation best fit by the sum of two exponentials, the time constants and relative amplitudes of which are indicated adjacent to the record. For I-Will there is an initial decrease in current, followed by a relaxation that is well fit by a single exponential function. $C$ plots mean values for the time constants of recovery of the response to kainate following cross-desensitization by I-Will and F-Will. Error bars represent SEM (four to seven cells per agonist).

blocks desensitization to AMPA, while ConA has only a weak effect (cf. Mayer and Vyklicky, 1989; Patneau et al., 1993; Wong and Mayer, 1993). Previous work by Huettner (1990), based on measurement of $\mathrm{EC}_{50}$ ratios for kainate versus domoate of 20fold in DRG neurons but only 4-fold in cortical neurons, suggested that kainate-preferring receptors show greater discrimination between agonists than AMPA-preferring receptors. Our studies confirm this and reveal that $(S)$-5-fluorowillardiine $\left(\mathrm{EC}_{50}\right.$ ratio for DRG vs hippocampus, 47-fold) and (S)-5-iodowillardiine $\left(E C_{50}\right.$ ratio for $D R G$ vs hippocampus, 137 -fold) show even more pronounced differences in selectivity for activation of glutamate receptors on DRG and hippocampal neurons. Such observations further substantiate our proposal that DRG neurons express predominantly kainate-preferring receptors, while hippocampal ncurons express predominantly AMPA-preferring receptors.
Structure-activity analysis suggests a hydrophobic site on kainate-preferring receptors

Two factors that would be expected to influence the potency of action of willardiines at glutamate receptors are the size and electron-withdrawing ability of the 5-substituent. Size would be important if the substituent fits into a pocket on the receptor surface; however, if the pocket is large, size per se would not be crucial within certain limits. The shape of the substituents, if not symmetrical, could also affect binding; to avoid this complication, the willardiines used in the present study had symmetrical substituents. The electron-withdrawing ability of the 5-substituents would be expected to affect agonist potency if as previously suggested (Patneau et al., 1992) the uracil ring in willardiines must lose a proton to generate a molecule containing ionized groups isosteric with the $\alpha-\mathrm{NH}_{2}, \alpha-\mathrm{COOH}$, and $\omega-\mathrm{COOH}$ 


\section{Domoate}

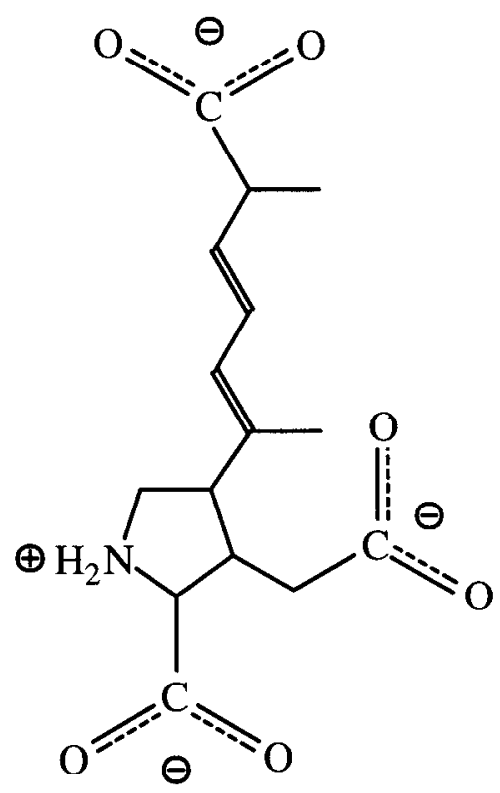

Kainate

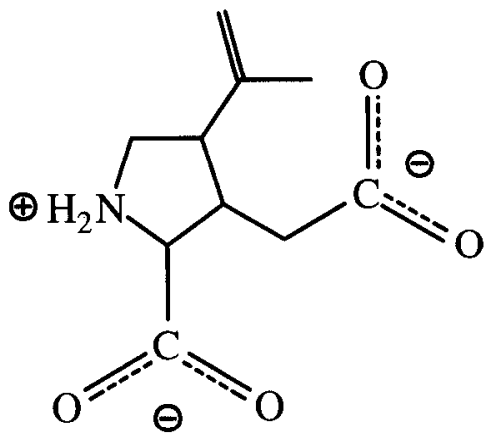

Willardiine<smiles>[R]c1cn(CC(N)C(=O)[O-])c(=O)[n-]c1=O</smiles>

Figure 9. Kainate receptor agonists share common structural features. Domoate and kainate have hydrophobic, unsaturated side chains; in domoate the side chain contains an electronegative carboxyl group; willardiine derivatives with hydrophobic, electron-withdrawing 5-substituents are also potent agonists at kainate-preferring receptors in DRG neurons.

groups in glutamate. Consistent with this, for activation of AMPA receptors there is a marked increase in potency versus willardiine for all derivatives for which the 5 -substituent is electron withdrawing (Table 2), while for 5-methylwillardiine, the only compound tested for which the substituent is electron repelling, the potency is lower than for willardiine itself. However, for activation of kainate-preferring receptors the potency sequence for willardiine and 5-methylwillardiine is the opposite of that for AMPA-receptors. This raises the possibility that hydrophobicity might also influence agonist action at kainate-preferring receptors, consistent with the lipophilic substituents in kainate and domoate (Fig. 9).

Table 2. Physicochemical parameters correlated with agonist potency for activation of AMPA- and kainate-preferring glutamate receptors by 5 -substituted willardiines

\begin{tabular}{lclrrr} 
Compound & $\begin{array}{c}\mathrm{DRG} \\
\mathrm{pEC}_{50}\end{array}$ & \multicolumn{1}{l}{$\begin{array}{l}\mathrm{HPC} \\
\mathrm{pEC}\end{array}$} & \multicolumn{1}{c}{$\mathrm{MR}$} & \multicolumn{1}{c}{$\sigma_{m}$} & \multicolumn{1}{c}{$\pi$} \\
\hline$(S)-5-\mathrm{CF}_{3}$ & 7.16 & 5.40 & 5.02 & 0.43 & 0.88 \\
$(S)-5-\mathrm{I}$ & 6.85 & 4.72 & 13.94 & 0.35 & 1.12 \\
$(S)-5-\mathrm{Br}$ & 5.87 & 5.06 & 8.88 & 0.39 & 0.86 \\
$(S)-5-\mathrm{Cl}$ & 5.70 & 5.14 & 6.03 & 0.37 & 0.71 \\
$(S)-5-\mathrm{F}$ & 4.16 & 5.83 & 0.92 & 0.34 & 0.14 \\
$(S)-5-\mathrm{NO}$, & 5.15 & 5.39 & 7.36 & 0.71 & -0.28 \\
$(S)-5-\mathrm{CN}$ & 5.05 & 5.43 & 6.33 & 0.56 & -0.57 \\
$(S)-5-\mathrm{CH}_{3}$ & 4.47 & 3.62 & 5.65 & -0.07 & 0.56 \\
$(S)-$ Will & $<3.0$ & 4.35 & 1.03 & 0.00 & 0.00 \\
\hline
\end{tabular}

Values for $\pi$ and MR are from Högberg and Norinder (1991); $\mathrm{pEC}_{50}$ (-ve log $E_{50}$ ) values were calculated from data used to generate Figure 3 and Table 1 . For hippocampal neurons, except for $\mathrm{CN}_{-}, \mathrm{CF}_{3^{-}}$, and Me-willardiine, $\mathrm{pEC}_{50}$ values were calculated from data In Patneau et al. (1992).
Table 2 gives potency values for willardiine derivatives in DRG and hippocampal neurons, together with indices for the 5-substituent related to size (MR, molar refractivity); electronwithdrawing ability $\left(\sigma_{m}=\log K_{x}-\log K_{H}\right.$, where $K_{H}$ and $K_{x}$ are the ionization constants for benzoic acid and a meta-substituted derivative, respectively); and hydrophobicity $\left(\pi=\log P_{x}-\log \right.$ $P_{H}$, where $P_{H}$ and $P_{x}$ are the partition coefficients between octanol and water of benzene and a meta-substituted derivative); values for MR, $\sigma_{m}$, and $\pi$ were taken from Högberg and Norinder (1991). Some idea of the relative importance of these factors in determining agonist potency can be gauged by comparison of the activity of compounds for which two parameters are similar and the third widely different. Such considerations suggest size of the 5-substituent to have only a limited influence for activation of kainate-preferring receptors in DRG neurons (e.g., Fig. $10 \mathrm{C}$ ), since comparisons between selected pairs of compounds lead to conflicting results. Thus, for the pair $\mathrm{CF}_{3}$ versus $\mathrm{Br}$, for which $\sigma_{m}$ and $\pi$ are similar but MR is greater for $\mathrm{Br}$ than for $\mathrm{CF}_{3}$, agonist potency decreases with increase in size; however, the opposite conclusion is reached from comparison of the $\mathrm{Cl}$ and $\mathrm{Br}$ derivatives. Indeed, 5-iodo-willardiine is an extremely potent agonist at kainate-preferring receptors, yet has by far the largest substituent, while 5-fluoro-willardiine, the weakest agonist, has the smallest substituent. It seems likely that within the limits explored here, size of the 5-substituent is less important than $\sigma_{m}$ or $\pi$ in determining agonist potency for activation of kainate-preferring receptors.

Similar to results obtained for AMPA-receptors, electronwithdrawing ability would be expected to play a role in determining agonist potency for activation of kainate-preferring receptors, if willardiines require charged groups isosteric with those in glutamate. That electron-withdrawing ability contributes to agonist potency for activation of kainate-preferring receptors is 

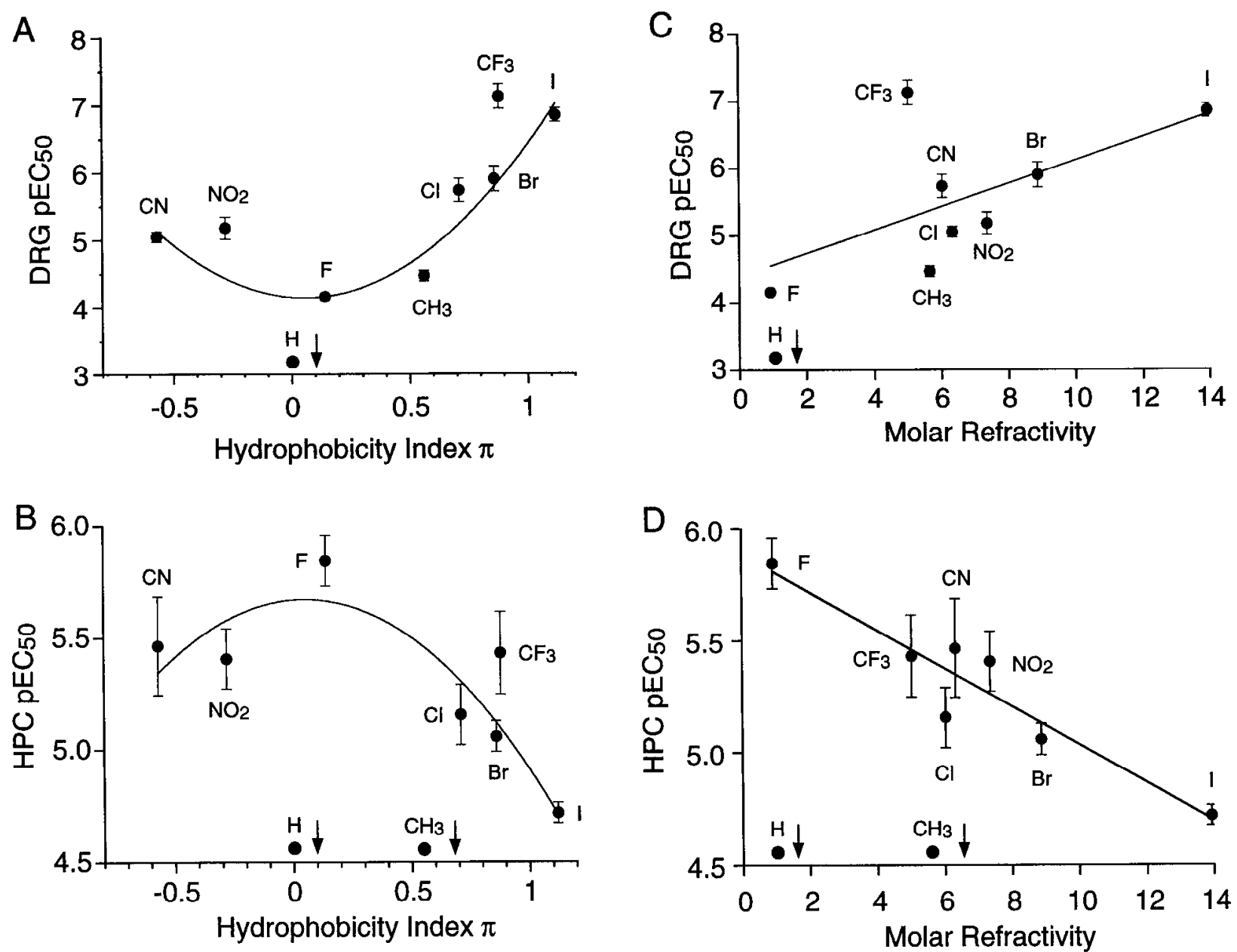

Figure 10. Structure-activity analysis for activation of kainate- and AMPA-preferring receptors by 5-substituted willardiines. $A$ shows a plot of $\mathrm{pEC}_{\mathrm{s} 0}$ versus the hydrophobicity index $(\pi)$ for responses recorded from kainate-preferring receptors in DRG neurons. The solid line shows a leastsquares fit of Equation 2; data points show mean + SD. $B$ shows a similar plot for AMPA-preferring receptors in hippocampal neurons. $C$ and $D$ plot $\mathrm{pEC}_{50}$ versus molar refractivity (MR) for responses recorded from hippocampal and DRG neurons, respectively; data points show mean \pm SD. Arrows adjacent to data points for willardiine $(H)$ in $A$ and $C$, and for willardiine and 5-methylwillardiine $\left(C H_{3}\right)$ in $B$ and $D$, indicate values off scalc (sce Tables 1, 2). Values for $\pi$ and MR were taken from Högberg and Norinder (1991).

suggested by data in Table 2; hence, the potency of $5-\mathrm{CF}_{3}-$ willardiine is greater than that of 5-I-willardiine even though the $\pi$ value for $\mathrm{CF}_{3}$ is less than that for $\mathrm{I}$, while the $\mathrm{NO}_{2}$ and $\mathrm{CN}$ derivatives are moderately potent agonists, despite the negative (i.e., hydrophilic) $\pi$ values for these substituents. Other comparisons leading to the same conclusion are the pairs $\mathrm{Cl}$ versus $\mathrm{CH}_{3}$-willardiine, and $\mathrm{F}$-versus unsubstituted willardiine, where $\sigma_{m}$ again appears to be the dominant factor.

The striking structure-activity relationship for the influence of hydrophobicity on activation of kainate receptors, illustrated in Figure $10 \mathrm{~A}$, leaves no doubt that this additional factor plays an important role in the agonist action of 5-substituted willardiines. Based on classical work by Hansch, Högberg and Norinder (1991) have proposed a relationship between hydrophobicity and biological activity for use in the quantitative analysis of structure-activity relationships for the hydrophobic interaction of drugs with receptors:

$$
\mathrm{pEC}_{50}=a \pi-b \pi^{2}+c
$$

Fits of the data obtained in our experiments on DRG neurons to this equation (Fig. 10A) gave a correlation coefficient of 0.96 $(a=-0.28, b=-2.53, c=4.16)$, with a marked increase in potency for willardiines with hydrophobic substituents, providing strong evidence for a hydrophobic site within the agonist binding site of kainate-preferring glutamate receptors. In contrast, for AMPA-preferring receptors in hippocampal neurons $(a-0.09, b=0.84, c=5.67$, correlation coefficient $=0.97)$ the correlation between $\pi$ and $\mathrm{pEC}_{50}$ was negative such that agonist potency decreases with increase in hydrophobicity (Fig. 10B). We believe the latter effect to be secondary to a strong negative correlation between MR and potency $(R=0.94)$ such that for activation of AMPA-preferring (Fig. $10 D$ ) but not kainate-preferring receptors (Fig. 10C) agonist potency decreases with size of the 5-substituent, as reflected in the opposite sequence for the halogens $\mathrm{F}, \mathrm{Cl}, \mathrm{Br}$, and $\mathrm{I}$. Our results suggest that further exploration of the role of hydrophobic substituents in parent molecules with different structures might lead to the development of novel antagonists with a selective action at kainateversus AMPA-preferring subtypes of glutamate receptor.

\section{Desensitization and prolonged kainate receptor occupancy by willardiines}

Our results suggest that the response of DRG neurons to willardiine analogs would be expected to occur with single-channel 
kinetics exhibiting unusually prolonged burst lengths. We did not test this directly because the low conductance of kainatepreferring glutamate receptor channels in DRG neurons (Huettner, 1990), and the long time constants expected for bursts and clusters of single-channel events produced by high-affinity agonists (e.g., Gibb and Colquhoun, 1992), would be expected to hinder direct measurement of gating kinetics by single-channel recording or noise analysis. An alternative approach used in the present study was to measure the rate of deactivation following the rapid removal of agonist. For NMDA receptors, results obtained with this approach are in good agreement with those obtained by single-channel analysis of equilibrium responses (Lester et al., 1990; Edmonds and Colquhoun, 1992; Gibb and Colquhoun, 1992; Lester and Jahr, 1992). In DRG neurons the deactivation of responses to 5-iodowillardiine, one of the most potent agonists examined with an $\mathrm{EC}_{50}$ of $140 \mathrm{nM}$, was well fit by the sum of two exponentials with time constants of $4.3 \mathrm{sec}$ $(78 \%)$ and $700 \mathrm{msec}(22 \%)$, much slower than described previously than for any other ligand-gated ion channel, and strikingly different from results obtained in hippocampal neurons for which we obtained deactivation time constants of $188 \mathrm{msec}$ (74\%) and $390 \mathrm{msec}(26 \%)$. Our experiments to measure the kinetics of deactivation in DRG neurons were performed following block of desensitization by ConA, and raise the possibility that for high-affinity agonists like $(S)$-5-iodowillardiine, entry into desensitized states normally truncates the burst of openings produced following the initial binding of agonist; the relatively rapid kinetics of onset of desensitization observed for 5-iodowillardiine, time constants of $64 \mathrm{msec}(45 \%)$ and 527 msec $(55 \%)$, provide strong support for this since desensitization occurs much faster than deactivation recorded following block of desensitization by ConA. For the interpretation of this experiment it is important to note that treatment with lectin does not alter agonist $\mathrm{EC}_{50}$ values for activation of kainate receptors in DRG neurons (Huettner, 1990). It is of interest that for AMPApreferring receptors the opposite conclusion has been drawn concerning the molecular mechanisms underlying truncation of ion channel activity following removal of agonist, based on the observation that the deactivation of responses to glutamate occurs faster than the onset of desensitization (Colquhoun et al., 1992; Hestrin, 1992). It is unlikely, however, that this is entirely due to differences in the gating properties of AMPA- versus kainate-preferring glutamate receptors per se, since for low-affinity agonists such as 5-fluorowillardiine and kainate, deactivation for kainate receptors in DRG neurons also occurs faster than the onset of desensitization (compare Figs. 5, 6).

Although Huettner (1990) proposed that recovery from desensitization evoked by application of glutamate, quisqualate, and AMPA to DRG cells for 2-3 min involves the slow conversion of unliganded, desensitized receptors to the resting, activatable state (time to full recovery, 3-6 $\mathrm{min}$ ), our results suggest additional mechanisms for recovery from desensitization, at least for desensitization evoked by agonist applications lasting only $2 \mathrm{sec}$. This raises the interesting possibility that for short and long applications of agonist, recovery from desensitization proceeds via different molecular pathways, perhaps involving the slow occupancy during a prolonged application of agonist of a desensitized state that, following dissociation of agonist, equilibrates slowly with the resting state. Our measurements for recovery from desensitization, which were obtained with shorter applications of agonist than used by Huettner (1990), revealed faster rates than obtained by Huettner, with marked agonist dependence of the recovery rate constants. For this to occur, under the conditions of our experiments there would have to be minimal occupancy of the unliganded desensitized state postulated by Huettner.

A major difference in the behavior of the response of native AMPA- versus kainate-preferring glutamate receptors to 5 -substituted willardiines is variation in the degree of equilibrium desensitization produced by different agonists in hippocampal (Fig. 1, 8) but not DRG neurons (Fig. 6). However, analysis of desensitization kinetics predicts this difference since, for kainate-preferring glutamate receptors, recovery from desensitization occurs relatively slowly compared to the kinetics of activation and deactivation even for low-affinity agonists such as 5-fluorowillardiine $\left(\mathrm{EC}_{50}=69 \mu \mathrm{M}\right.$; principle time constant of recovery from desensitization, $3.9 \mathrm{sec}$; principle time constant of deactivation, $44 \mathrm{msec}$ ). As a result, entry into the desensitized state is effectively an absorbing event for willardiine responses at kainate-preferring receptors. In contrast, for AMPA-preferring receptors in hippocampal neurons the kinetics of recovery from desensitization for willardiines are much faster than in DRGs, such that the desensitizing state of AMPA-preferring receptors is not absorbing, and even high-affinity agonists like 5-fluorowillardiine $\left(\mathrm{EC}_{50}=1.5 \mu \mathrm{M}\right)$ produce inward current responses at equilibrium. Taken together, our estimates for agonist $\mathrm{EC}_{50}$ values, deactivation kinetics, and desensitization kinetics in DRG and hippocampal neurons lead to the conclusion that for kainate-preferring glutamate receptors in DRG neurons both agonist-activated and desensitized receptor states form considerably more stable complexes with willardiines than do AMPApreferring glutamate receptors in hippocampal neurons.

\section{References}

Agrawal SG, Evans RH (1986) The primary afferent depolarizing action of kainate in the rat. Br J Pharmacol 87:345-355.

Boulter J, Hollmann M, O'Shea-Greenfield A, Hartley M, Deneris E, Maron C, Heinemann S (1990) Molecular cloning and functional expression of glutamate receptor genes. Science 249:1033-1037.

Collingridge GL, Lester RA (1989) Excitatory amino acid receptors in the vertebrate central nervous system. Pharmacol Rev 41:143-210.

Edmonds B, Colquhoun D (1992) Rapid decay of single-channel NMDA receptor activations recorded at low agonist concentrations. Proc $R$ Soc Lond [Biol] 250:279-286.

Gibb AJ, Colquhoun D (1992) Activation of $N$-methyl-D-aspartate receptors by L-glutamate in cells dissociated from adult rat hippocampus. J Physiol (Lond) 456:143-179.

Hamill OP, Marty A, Neher E, Sakmann B, Sigworth FJ (1991) Improved patch-clamp techniques for high-resolution current recording from cells and cell-free membrane patches. Pfluegers Arch 391:85100

Herb A, Burnashev N, Werner P, Sakmann B, Wisden W, Seeburg PH (1992) The KA-2 subunit of excitatory amino acid receptors shows widespread expression in brain and forms ion channels with distantly related subunits. Neuron 8:775-785.

Hestrin S (1992) Activation and desensitization of glutamate-activated channels mediating fast excitatory synaptic currents in the visual cortex. Neuron 9:991-999.

Högberg T, Norinder U (1991) Theoretical and experimental methods in drug design applied on antipsychotic dopamine antagonists. In: A textbook of drug design and development (Krogsgaard-Larsen P, Bundgaard H, eds), pp 55-91. Chur, Switzerland: Harwood.

Hollman M, Heinemann S (1994) Cloned glutamate receptors. Annu Rev Neurosci 17:31-108.

Huettner JE (1990) Glutamate receptor channels in rat dorsal root ganglion neurons: activation by kainate and quisqualate, and blockade of desensitization by concanavalin A. Neuron 5:255-266.

Keinänen K, Wisden W, Sommer B, Werner P, Herb A, Verdoorn TA, Sakmann B, Seeburg PH (1990) A family of AMPA-selective glutamate receptors. Science 249:556-560. 
Kiskin NI, Krishtal OA, Tsyndrenko AY (1986) Excitatory amino acid receptors in hippocampal neurons: kainate fails to desensitize them. Neurosci Lett 63:225-230.

Lester RAJ, Jahr CE (1992) NMDA channel behavior depends on agonist affinity. J Neurosci 12:635-643.

Lester RAJ, Clements JD, Westbrook GL, Jahr CE (1990) Channel kinetics determine the time course of NMDA receptor-mediated synaptic currents. Nature 346:565-567.

Lomeli H, Sprengel R, Laurie DJ, Köhr G, Herb A, Seeburg PH, Wisden W (1993) The rat delta-1 and delta-2 subunits extend the excitatory amino acid receptor family. FEBS Lett 315:318-322.

Mayer ML, Vyklicky L Jr (1989) Concanavalin A selectively reduces desensitization of mammalian neuronal quisqualate receptors. Proc Natl Acad Sci USA 86:1411-1415.

Mayer ML, Vyklicky L Jr, Westbrook GL (1989) Modulation of excitatory amino acid receptors by group IIB metal cations in cultured mouse hippocampal neurones. J Physiol (Lond) 415:329-350.

Mayer ML, Patneau DK, Vyklicky L (1992) Desensitization, drugs, and synaptic transmission at AMPA/kainate receptors. In: Excitatory amino acids (Simon RP, ed), pp 125-131. New York: Thieme.

Mintz IM, Adams ME, Bean BP (1992) P-type calcium channels in rat central and peripheral neurons. Neuron 9:85-95.

Nakanishi N, Shneider NA, Axel R (1990) A family of glutamate receptor genes: evidence for the formation of heteromultimeric receptors with distinct channel properties. Neuron 5:569-581.

Nohno T, Saito T, Hong JS (1986) Cloning and complete nucleotide sequence of the Escherichia coli glutamine permease operon (gln HPQ). Mol Gen Genet 205:260-269.

Partin KM, Patneau DK, Winters CA, Mayer ML, Buonanno A (1993) Selective modulation of desensitization at AMPA versus kainate receptors by cyclothiazide and concanavalin A. Neuron 11:1069-1082.

Patneau DK, Mayer ML (1990) Structure-activity relationships for amino acid transmitter candidates acting at $N$-methyl-D-aspartate and quisqualate receptors. J Neurosci 10:2385-2399.

Patneau DK, Mayer ML (1991) Kinetic analysis of interactions between kainate and AMPA: evidence for activation of a single receptor in mouse hippocampal neurons. Neuron 6:785-798.
Patneau DK, Mayer ML, Jane DE, Watkins JC (1992) Activation and desensitization of AMPA/kainate receptors by novel derivatives of willardiine. J Neurosci 12:595-606.

Patneau DK, Vyklicky L Jr, Mayer ML (1993) Hippocampal neurons exhibit cyclothiazide-sensitive rapidly desensitizing responses to kainate. J Neurosci 13:3496-3509.

Sakimura, K, Morita, T, Kushiya E, Mishina M (1992) Primary structure and expression of the $\gamma 2$ subunit of the glutamate receptor selective for kainate. Neuron 8:267-274.

Sommer B, Seeburg PH (1992) Glutamate receptor channels: novel properties and new clones. Trends Pharmacol Sci 13:291-296.

Sommer B, Burnashev N, Verdoorn TA, Keinänen K, Sakmann B, Seeburg PH (1992) A glutamate receptor channel with high affinity for domoate and kainate. EMBO J 11:1651-1656.

Watkins JC, Evans RH (1981) Excitatory amino acid transmitters. Annu Rev Pharmacol Toxicol 21:165-204.

Watkins JC, Krogsgaard-Larsen P, Honoré T (1990) Structure-activity relationships in the development of excitatory amino acid receptor agonists and competitive antagonists. Trends Pharmacol Sci 11:2533.

Wong LA, Mayer ML (1993) Differential modulation by cyclothiazide and concanavalin $\mathrm{A}$ of desensitization at native $\alpha$-amino-3-hyroxy5-methyl-4-isoxazoleproprionic acid- and kainate-preferring glutamate receptors. Mol Pharmacol 44:504-510.

Wong LA, Mayer ML, Jane DE, Watkins JC (1992) Characterization of kainate receptors in rat dorsal root ganglion (DRG) neurons using novel $S$-willardiine analogs. Soc Neurosci Abstr 18:86.

Yamada K, Tang C-M (1993) Benzothiadiazines inhibit rapid glutamate receptor desensitization and enhance glutamatergic synaptic currents. J Neurosci 13:3904-3915.

Yamazaki M, Araki K, Shibata A, Mishina M (1992) Molecular cloning of a cDNA encoding a novel member of the mouse glutamate receptor channel family. Biochem Biophys Res Commun 183:886892. 